Research Article/Araştırma Makalesi

\title{
Instructional Explanations of Mathematics Teachers and Preservice Teachers on Misconceptions: The Subject of Probability
}

\author{
Gülsüm Gülşah BURSALI *1 (D) Burçin GÖKKURT ÖZDEMİR ${ }^{2}$ \\ ${ }^{1}$ Bartm University, Graduate School of Educational Sciences, Bartın, Turkey, gulsahcan_60@hotmail.com \\ ${ }^{2}$ Bartın University, Faculty of Education, Bartın, Turkey, gokkurtburcin@gmail.com \\ * Corresponding Author: gokkurtburcin@gmail.com
}

\begin{tabular}{|c|c|}
\hline Article Info & Abstract \\
\hline $\begin{array}{l}\text { Keywords: Misconception, } \\
\text { probability, teacher, preservice } \\
\text { teacher }\end{array}$ & $\begin{array}{l}\text { The aim of this study is to examine the awareness of mathematics } \\
\text { teachers and preservice teachers on misconceptions related to the } \\
\text { subject of probability and their instructional explanations about which } \\
\text { methods should be used to correct these misconceptions. The study } \\
\text { was carried out with six mathematics teachers and three preservice } \\
\text { teachers studying in the } 4 \text { th grade of a state university's secondary } \\
\text { school mathematics teaching program. The case study method was } \\
\text { used in the study. The interview form consisting of nine questions was } \\
\text { used as the data collection tool. As a result of the research, it was } \\
\text { determined that teachers and preservice teachers could generally } \\
\text { identify the misconceptions related to a positive-negative regency } \\
\text { effect, simple and compound events. }\end{array}$ \\
\hline \multicolumn{2}{|l|}{ Publication Language: Turkish } \\
\hline open 2 access & $\begin{array}{l}\text { To cite this article: Bursall, G. G., \& Gökkurt-Özdemir, B. (2019). } \\
\text { Instructional explanations of mathematics teachers and preservice } \\
\text { teachers on misconceptions: the subject of probability. Journal of } \\
\text { Computer and Education Research, 7(14), 642-672. DOI: } \\
\text { 10.18009/icer.639384 }\end{array}$ \\
\hline
\end{tabular}

\section{Matematik Öğretmenlerinin ve Öğretmen Adaylarının Kavram Yanılgılarına Yönelik Öğretimsel Açıklamaları: Olasılık Konusu}

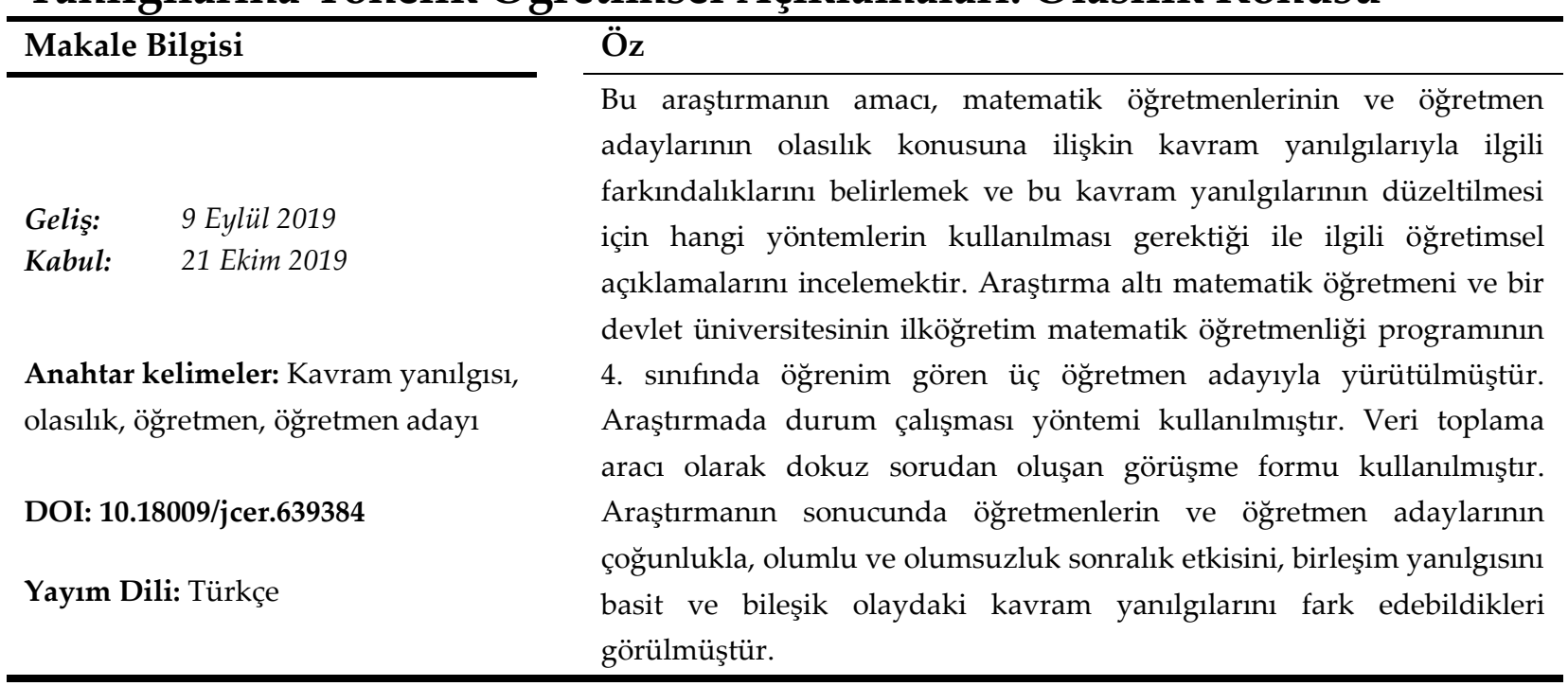




\title{
Summary
}

\section{Instructional Explanations of Mathematics Teachers and Preservice Teachers on Misconceptions: The Subject of Probability}

\begin{abstract}
Introduction
Probability, one of the most effective subjects that develop the creative and independent thinking skills among the skills included in the curriculum, is a field of mathematics that enriches student's different perspectives on events and improves their thought horizons. In many studies, it is observed that students have difficulty in understanding the subject of probability, moreover, students cannot escape from the difficulties related to probability even though this subject is learned by them during the teaching period. When the literature was examined, it was found out that the reasons for learning difficulties experienced in probability were students' negative attitudes, the lack of reasoning skills, readiness level, misconceptions, teacher and age. The misconception is the most important reason among them because misconceptions are one of the important factors that prevent the conceptual learning of students. Therefore, teachers who have an important role in the teaching process should be aware of the misconceptions in learning environments and remove these misconceptions. Similarly, the fact that preservice teachers who receive preservice training are also aware of misconceptions is important for them to become qualified teachers. For this purpose, teachers should have knowledge about the misconceptions, be aware of the misconceptions in students and use appropriate methods and techniques in the removal of these misconceptions to ensure that the subject of probability is learned correctly. In this context, instructional explanations of mathematics teachers and preservice teachers on misconceptions related to the subject of probability were examined in the study. In this regard, the participants were asked for their opinions about whether they were aware of the misconceptions related to probability and about what these misconceptions are and their reasons. Furthermore, their opinions about which method techniques should be used to correct these misconceptions were also included.
\end{abstract}




\section{Method}

The case study method based on the qualitative approach was used in the study. The study was carried out in the fall semester of the 2016-2017 academic years. 3 high school, 3 secondary school teachers working at two high schools and secondary school located in the province and districts of Bartin, and three preservice teachers studying in the 4th grade of a state university's elementary education school mathematics teaching program were determined to be the participants. The purposeful sampling method was used in the selection of the participants. The interview form consisting of nine questions was used as the data collection tool. The questions in the interview form consist of teaching scenarios involving different misconceptions about probability. The questions related to misconceptions in the national and international literature were used in teaching scenarios. Interviews were held by taking sound recording with a semi-structured interview technique. The expert opinions were taken to ensure the validity while creating the interview form. In line with the expert opinions, unclear statements in some scenarios were corrected and made more understandable. A pilot application was performed for the reliability of the study. The qualitative analysis techniques were used in the analysis of the data obtained from the study. Furthermore, direct quotations from the participants were also included to present a detailed picture of the study.

\section{Results}

When the study findings were examined, it was found out that teachers and preservice teachers usually could not identify the union error, fell into the co-probability bias error and could not recognise the result-oriented misconception. It was also found out that they had misconceptions about the concepts of discrete events and independent events and confused these concepts. In particular, high school mathematics teachers could not identify the union error included in the secondary education mathematics curriculum. It was seen that preservice teachers could not distinguish discrete event and independent event in particular. It was determined that secondary school teachers were more aware of the misconceptions compared to other two groups. Teachers and preservice teachers stated that they generally preferred the narrative expression or the use of materials such as money and dice for the elimination of these misconceptions in the case of encountering the misconceptions included in the scenarios in the course environment. 


\section{Discussion and Conclusion}

In the light of the findings of the study, it was determined that teachers and preservice teachers could generally identify the misconceptions related to a positive-negative regency effect, the incorrect use of the proportional model, simple and compound events, representativeness heuristic and conditional probability. In addition, it was generally observed that they could not identify the union error, co-probability bias and the resultoriented misconception and confused the discrete event and independent event. Moreover, it was observed that they were not aware of the methods (concept maps, concept cartoons, etc.) that are effective in eliminating misconceptions and that they preferred to use the narrative expression and the use of materials. 


\section{Giriş}

Matematik, tüm bilimlerle etkileşim içinde, onlardan etkilenen ve onları direk ya da dolaylı olarak etkileyen formel bir disiplindir. Matematik ve matematiksel düşünce biçimi hayatın her alanına yerleşmiştir ve ondan bağımsız bir yaşam mümkün değildir (Işık, Kaplan, \& Zehir, 2011). Matematik eleştirel düşünme, yaratıcı düşünme, iletişim, araştırmasorgulama genelleme yapabilme, yaratıcı ve bağımsız düşünebilme, problem çözme becerisi gibi birçok düşünme biçimini içererek hem bireyin zihinsel gelişimine katkı sağlar, hem de bireye günlük hayat durumlarında yardımcı olur. Dolayısıyla üst düzey davranışları ve kazanımları geliştiren bir alan olarak matematiğin öğrenilmesi bir zorunluluktur (Moralı, Köroğlu, \& Çelik, 2004).

Salan ve Gence (1998), öğretim programlarında yer alan becerilerden yaratıcı ve bağımsız düşünme becerisini geliştiren en etkin konulardan biri olan olasılığın, öğrencinin olaylara farklı bakış açılarını zenginleştiren sağlayan ve düşünce ufkunu geliştiren bir matematik alanı olduğunu belirtmektedir (Akt. Işık, Kaplan, \& Zehir, 2011). Ayrıca olasılık günlük hayata yer etmiş bir olgudur. Pozitif bilim dallarında ve insan bilimleri ile ilgili dallarda olasılık kavramından yararlanılmaktadır (Bulut, Ekici, \& İnan-İşeri, 1999). Birçok meslekte, günlük hayatta aldığımız pek çok kararda önemli bir role sahip olan olasılık, meteoroloji tahminlerinden, hastalık risklerinde, ilaç deneylerinde gibi konuda etkili ve yoğun bir şekilde kullanılmaktadır (Hirsch \& O’Donnell, 2001). Türkiye'de öğretim programındaki yeniliklerle olasılık konusu basit tahmin durumları ile 4 . ve 5. sinif, permütasyon kombinasyon ve olasılık hesaplama konuları ile de 6-8 sınıf müfredatlarına eklenmiştir (Kazak, 2013).

Birçok araştırmacı olasılık konusunun kavranmasında, olasılık durumlarının hesaplanmasında öğrencilerin zorluk yaşadığını belirtmiştir (Batanero, Serrano, \& Garfield, 1996; Fischbein \& Schnarch, 1997; Shaughnessy, 1992). Boyacıŏlu, Erduran ve Alkan (1996) da yaptı̆̆ sıralamasında permütasyon ve olasılık konusunu listenin başında olduğunu belirtmişlerdir. Literatürde olasılık konusunun öğrenilememesinin çeşitli nedenleri vardır (Boyacıŏlu, Erduran, \& Alkan, 1996; Bulut, Ekici, \& İnan-İşeri,1999; Ertem-Akbaş \& Gök, 2018; SevLekesiz, 2011; Tunç, 2006). Sezgin-Memnun (2008a), olasılık konusunun öğrenilmesinde ne tür problemler yaşandığını ve bu problemlerin nelerden kaynaklandığını balık kılçığı diyagramı ile göstermiştir. Bu diyagramda, olasılık konusunun öğrenilememe sebeplerinden 
başlıcaları arasında öğrencinin hazırbulunuşluk düzeyi, öğrencinin yaşı, öğrencinin muhakeme etme becerisinin yetersizliği, öğretmen, kavram yanılgısı ve öğrencinin olumsuz tutumu olarak belirlemiştir.

Olasılık konusunun öğrenilmesinde zorluk çekilmesindeki en önemli etkenlerden biri de öğrencilerin, öğretmen adaylarının ya da öğretmenlerin konuyla ilgili çeşitli kavram yanılgılarının varlığıdır (Gökkurt-Özdemir, 2017; Kazak, 2013; Sezgin-Memnun, 2008a). Erbaş, Çetinkaya ve Ersoy (2009) kavram yanılgısıyla ilgili yapılan araştırmalardan yola çıkarak matematiksel kavram yanılgısını, 'Bir öğrencinin uzun süreden beri doğru olarak kabul ettiği, birden fazla durumda ortaya çıkan, kolay değişmeyen ve matematiksel gerçeklerle çelişen kavramalar şeklinde tanımlamışlardır. Kavram yanılgıları hem mevcut konunun anlaşılmasını engellediği gibi aynı zamanda kendisinden sonra öğretilecek birçok konuda yeni kavram yanılgıları oluşmasına sebep olabilir (Şandır, Ubuz \& Argün, 2007). Ulusal ve uluslararası çalışmalara bakıldığında, öğrencilerin olasılık konusunda kavram yanılgılarına sebep olan durum, öğrencilerin olasılık kavramlarını anlamayı sezgisel olarak anlamakta zorlanmalarıdır (Fischbein \& Schnarch, 1997; Shaughnessy, 1992). Yapılan araştırmalara göre, olasılık konusundaki kavram yanılgıları temsil kısa yolu, sonuç yaklaşımı, olumsuz sonralık etkisi ve olumlu sonralık etkisi, eşit olasılık yanlılı̆̆ı, orantı modelin yanlış kullanımı, birleşim yanılgısı, basit ve birleşik olaylar, koşullu olasılık olarak alt başlıklara ayrılmıştır (Fischbein \& Schnarch, 1997; Shaughnessy, 1992). Ayrıca Altun (2008) öğrencilerin bağımsız olaylar ile ayrık olayları karıştırdığını ifade etmiştir. Benzer şekilde Gökkurt-Özdemir (2017), öğretmen adaylarının bağımlı-bağımsız olay, ayrık olayayrık olmayan olay kavramlarında yanılgılara sahip olduklarını göstermiştir. Literatürde pek çok araştırmada öğrencilerin (Akkoç \& Yeşildere-İmre, 2015) ve öğretmen adaylarının (Schoen, LaVenia, Chicken, Razzouk, \& Kisa, 2019) bu konuda kavram yanılgılarına sahip olduklarını göstermektedir.

Olasılık konusunda kavram yanılgısı türlerinden biri olan temsil kısa yolu, sezgiye dayalı hataya sebep olur ve Kahneman ve Tversky'e (1972) göre bir olayın olma olasılı̆̆ının, o olayın örneklem uzayı ne kadar iyi yansıttı̆̆ına göre değerlendirilme durumudur. Örneğin, hilesiz bir paranın atılma deneyinde seçeneklerden düzenli sıra içeren TYTYTYTYTY ve uzun tekrar içeren TTTTTTTTTY sonuçları, öğrenciler tarafından daha az rasgele olarak algılanmaktadır. Öğrenciler, seçenekler arasında uzun süre devamlı aynı yüzün gelmemesini düşündüklerinden olasılığı daha iyi temsil edeceği YTYYYTTYTT 
sıralamasını diğerlerine nazaran tercih etmişlerdir (Shaughnessy, 1992). Benzer şekilde, çoğu insan altı diziden oluşan bir yazı tura atma olayında TTTTTT dizisinin TYYTYT dizisinden daha az meydana geldiğini düşünmektedir (Baki, 2008).

Sonuç yaklaşımı, bir olayın olma olasılığını tahmin etmek yerine, olayın kesinliği için yorum yapmaya ve karar vermeye çalışmak olarak tanımlanmıştır (Shaughness, 1993). Örneğin \%70 olasılıkla yağmur yağacağı söylendiğinde, bu yanılgıya sahip kişiler yağmurun kesin olarak yağacağını; yağmur yağma olasılığı \%30 şeklinde ifade edildiğinde ise bu kez yağmurun yağmayacağını düşünürler (Jun, 2000'den aktaran Hayat, 2009). Olumsuz sonralık etkisi, iki olası sonucu bulunan (yazı-tura gibi) olaylarda ard arda yapılan denemelerde bir sonraki sonuç için önceden daha az gerçekleşen çıktıyı tahmin etme eğiliminde bulunma, olumlu sonralık etkisi ise iki olası sonucu bulunan olaylarda ard arda yapılan denemelerde bir sonraki sonuç için önceden gerçekleşen çıktının daha fazla olma ihtimalini tahmin etme eğiliminde bulunma olarak ifade edilmiştir (Kahneman \& Tversky, 1972). Örneğin hilesiz bir paranın 3 kere havaya atılması sonucunda ard arda 3 kere tura geliyorsa olumsuz sonralık etkisine sahip bireyler, dördüncü atışta tura gelme ihtimalinin yazı gelme ihtimalinden düşük, olumlu sonralık etkisine sahip bireyler ise yazı gelme ihtimalinin tura gelme ihtimalinden düşük olduğunu düşünmektedir (Fischbein \& Schnarch,1997). Eşit olasıllk yanlılı̆̆ını Lecottre (1992) bir olayın bütün çıktılarının eşit olasılıklı görmeye eğilimli olma durumu olarak açıklamış ve yaptığı araştırmada 'Hilesiz iki zar havaya atıldığında üste gelen sayılar toplamının 9 ve 11 gelme olasılı̆̆ı nedir?' sorusunu kullanmış, sonuçta öğrencilerin iki durumu eş olasılıklı görme eğiliminde olduğunu görmüştür (akt. Kazak, 2013). Orantı modelin yanlış kullanımı, 'örneklem büyüklüğü ve deneme sayısı arttıkça olasılık sonucu teorik olasılık değerine yaklaşır' şeklindeki büyük sayılar yasasının ihmal etme durumuyla oluşur. Havaya 3 kere atılan hilesiz bir madeni paranın en az 2 defa tura gelme olasılığı ile 300 kere atılmasında en az 200 defa tura gelme olasılığı eş olasılık olarak düşünülmesi bu kavram yanılgısına örnektir. Birleşim yanılgısı ile ilgili Watson ve Moritz (2002) yaptıkları çalışma sonucunda, bu yanılgıyı iki olayın birlikte gerçekleşme olasılığı bu olayların ayrı ayrı gerçekleşme olasılığından daha yüksek olduğunun düşünülmesi olarak ifade etmişlerdir (akt. Kazak, 2013). Ayrıca basit ve bileşik olaylarda, iki olayın beraber veya birlikte meydana gelmesinde, koşullu olasılık durumlarında bağımlı olayın bağlı olduğu olaydan daha sonra gerçekleştiği gibi durumlarda kavram yanılgısı olabilmektedir (Hayat, 2009; Kazak, 2013; Tunç, 2006). 
Olasılık konusunun öğrenilmesini zorlaştıran önemli sebeplerden biri olan kavram yanılgısıyla ilgili literatür tarandığında, öğrencilerin, öğretmenlerin ve öğretmen adaylarının bahsedilen kavram yanılgılarına sahip olup olmadıkları incelenmiştir (Bulut, Yetkin, \& Kazak, 2002; Işık, Kaplan \& Zehir, 2011; Sev-Lekesiz, 2011; Tunç, 2006). Olasılık konusunun öğrenilmesinin kolaylaştırılması ve zorlukların giderilmesi için de (Bulut, Ekici, \& İnan-İşeri, 1999; Erbaş, Çetinkaya \& Ersoy, 2009; Sezgin-Memnun, 2008b) gerekli çalışmalar yapılmış ancak genellikle öğrencilerin anlama güçlükleri üzerinde durulduğu, öğretmenlerin ve öğretmen adaylarının (Gökkurt-Özdemir, Bayraktar, \& Yılmaz, 2017) kavram yanılgılarının farkındalıkları konusunda sınırlı sayıda araştırmaya rastlandığı görülmektedir. Bu araştırmaların da daha çok Sayılar ve İşlemler öğrenme alanında yapıldığı görülmektedir. Olasılık konusunda öğrenme zorluklarının ortadan kaldırılması için öğrencilerdeki kavram yanılgılarının giderilmesi gerektiği ve bunun sağlanması için öncelikle eğitim öğretimde önemli rol oynayan öğretmenlerin ve öğretmen adaylarının kavram yanılgılarının farkında olmaları gerektiği düşünülmektedir. Konu hakkındaki kavram yanılgıları hakkında bilgi sahibi olan öğretmen, bu bilinçle öğretimi gerçekleştirebileceği ve zorluklar yaşanmasına engel olmakla birlikte öğretimini etkili bir şekilde gerçekleştirebileceği düşünülmektedir. Bu doğrultuda, araştırmanın amacı ve alt problemleri aşağıda verilmiştir.

\section{Araştırmanın Amacı}

$\mathrm{Bu}$ araştırmanın amacı, matematik öğretmenlerinin ve öğretmen adaylarının olasılık konusuna ilişkin kavram yanılgılarıyla ilgili farkındalıklarını belirlemek, bu kavram yanılgılarının ne olduğu ve giderilmesi için tercih ettikleri yöntemlere ilişkin öğretimsel açılamalarını incelemektir. Bu amaç doğrultusunda alt problemler şu şekildedir:

1. Öğretmenlerin ve öğretmen adaylarının olasılık konusuna ilişkin kavram yanılgılarının ne olduğu ve nedenleri hakkında öğretimsel açıklamaları nedir?

2. Öğretmenlerin ve öğretmen adaylarının olasılıkla ilgili yanılgıların giderilmesi için kullanmayı tercih ettikleri yöntem ve teknikler nelerdir? 


\section{Yöntem}

\section{Araştırma Modeli}

Bu çalışmada, nitel yaklaşıma dayalı durum çalışması yöntemi kullanılmıştır. Durum çalışması, olgu veya olayı derinlemesine incelenmesine olanak veren bir araştırma yöntemidir (Yıldırım \& Şımşek, 2013). Araştırmada, öğretmenlerin kavram yanılgılarının belirlenmesi ve bu yanılgıların giderilmesi hususunda tercih ettikleri yöntemlere ilişkin öğretimsel açıklamaları detaylı incelendiğinden bu yöntemin kullanılması tercih edilmiştir.

\section{Katılımcilar}

$\mathrm{Bu}$ araştırmanın katılımcılarını, Bartın ilinde bulunan iki lise ve ortaokulda görev yapan 3 lise, 3 ortaokul öğretmeni ve bir devlet üniversitesinin ilköğretim matematik öğretmenliği programının son sınıfında öğrenim gören 3 öğretmen adayı olarak belirlenmiştir. Olasılık konusu hem ortaokul, hem de ortaöğretim matematik dersi öğretim programında öğrenme alanlarından biri olduğundan araştırmaya hem ortaokul, hem de lise öğretmenleri dâhil edilmiştir. Katılımcıların demografik özellikleri Tablo 1'de verilmiştir.

Tablo 1. Katılımcıların demografik özellikleri

\begin{tabular}{cccc}
\hline Katılımcılar & Bay & Bayan & $\begin{array}{c}\text { Mesleki } \\
\text { Kidem }\end{array}$ \\
\hline $\mathrm{A}_{1}$ & $\sqrt{ }$ & 0 \\
\hline $\mathrm{A}_{2}$ & & $\sqrt{ }$ & 0 \\
\hline $\mathrm{A}_{3}$ & $\sqrt{ }$ & & 0 \\
\hline $\mathrm{L}_{1}$ & $\sqrt{ }$ & 15 \\
\hline $\mathrm{L}_{2}$ & & $\sqrt{ }$ & 15 \\
\hline $\mathrm{L}_{3}$ & $\sqrt{ }$ & & 4 \\
\hline $\mathrm{O}_{1}$ & & $\sqrt{ }$ & 12 \\
\hline $\mathrm{O}_{2}$ & $\sqrt{ }$ & & 12 \\
\hline $\mathrm{O}_{3}$ & & $\sqrt{ }$ \\
\hline
\end{tabular}

Katılımcıların kimliklerini gizli tutmak amacıyla matematik öğretmen adaylarına $\mathrm{A}_{1^{\prime}}$ $A_{2}$ ve $A_{3^{\prime}}$ ortaokul matematik öğretmenlerine $\mathrm{O}_{1^{\prime}} \mathrm{O}_{2}$ ve $\mathrm{O}_{3^{\prime}}$, lise matematik öğretmenlerine ise $\mathrm{L}_{1}, \mathrm{~L}_{2}$ ise $\mathrm{L}_{3}$ şeklinde kodlar verilmiştir. 
Veri Toplama Araçları

Veri toplama aracı hazırlanmadan önce araştırmacılar tarafından literatür taraması yapılmıştır. Sorular senaryo biçiminde olup ulusal ve uluslararası literatürde (Hayat, 2009; Kahneman \& Tversky, 1972; Kazak, 2013; Shaughness, 1993) belirtilen olasılık konusundaki çoğu kavram yanılgısını içermektedir. Senaryolara daha önce yapılan çalışmalarda kullanılan kavram yanılgısı içeren durumlar verilmiştir. Senaryolar, öğretmen öğrenci diyalogları, sınıf ortamındaki öğrenciler arası konuşmalar şeklinde düzenlenmiştir. Araştırmacıların deneyimi ve soruların kullanışlılığının kontrolü açısından faydası olacağı düşünüldüğünden bir öğretmen adayı ve öğretmen ile pilot uygulama yapılmıştır. Senaryoda yanlış anlaşılmaya sebep olan birkaç düzeltme uzman görüşü alınarak düzeltilmiştir. Düzeltilen senaryolar katılımcılara görüşme tekniği kullanılarak uygulanmış, yaklaşık 35-40 dk süresince uygulanmıştır. Tablo 2' de soru örneklerine yer verilmiştir.

Tablo 2. Soru örnekleri

\begin{tabular}{|c|c|}
\hline Kavram yanılgısı türü & Öğretim Senaryosu \\
\hline \multirow{5}{*}{$\begin{array}{l}\text { Olumsuz ve olumlu } \\
\text { sonralık etkisi }\end{array}$} & $\begin{array}{l}\text { Matematik öğretmeni olan Ahmet Hoca öğrencilere } \\
\text { olasılık konusunu anlatırken cebinden bir bozuk para } \\
\text { çıkarıp üç kere havaya atarak sonuçları sırayla tahtaya } \\
\text { yazıyor: Tura, Tura, Tura. Ahmet Hoca öğrencilere } \\
\text { 'Dördüncü kere havaya attı̆̆ımda yazı gelme olasılığı nedir? } \\
\text { Şeklinde soru yöneltmiştir. } \\
\text { Öğrencilerden Ayşe söz hakkı alarak 'Bence tura gelme } \\
\text { olasıllğı yazı gelme olasılı̆̆ından yüksektir' şeklinde cevap } \\
\text { vermiştir. }\end{array}$ \\
\hline & $\begin{array}{l}\text { Öğretmen ayrıca öğrencilerden Özge'ye de söz hakkı } \\
\text { vermiş ve o da 'Öğretmenim sürekli tura geldi sıra yazı } \\
\text { gelmesinde, bence yazı gelme olasıllğ̆ daha yüksektir. } \\
\text { 'demiştir. }\end{array}$ \\
\hline & $\begin{array}{l}\text { A-Size göre Ayşe'nin veya Özge'nin cevabı doğru } \\
\text { mudur? Doğru değilse nedenini açıklayınız. }\end{array}$ \\
\hline & $\begin{array}{l}\text { B-Size göre öğrencilerin cevabı kavram yanılgısı içerir } \\
\text { mi? Eğer içerdiğini düşünüyorsanız kavram yanılgısının } \\
\text { ne olduğunu ve nedenini açıklayınız. }\end{array}$ \\
\hline & $\begin{array}{l}\text { C-Ĕger kavram yanılgısı olduğunu düşünüyorsanız bu } \\
\text { kavram yanılgısını düzeltmek için hangi yöntemleri } \\
\text { kullanırdınız? }\end{array}$ \\
\hline $\begin{array}{l}\text { Orantılı modelin yanlış } \\
\text { kullanımı }\end{array}$ & $\begin{array}{l}\text { İlayda Öğretmen olasılık konusunu anlatırken tahtaya } \\
\text { yazdığı " Hilesiz bir madeni paranın havaya } 3 \text { kez atıldığında } \\
\text { en az } 2 \text { defa tura gelme olasılı̆̆ı ve } 300 \text { kez atıldığında en az } \\
200 \text { kere tura gelme olasılıklarını hesaplayınız' sorusunu }\end{array}$ \\
\hline
\end{tabular}




öğrencilere yöneltmiştir. Söz hakkı alan
Mehmet,'Öğretmenim,
3 kez atıldığında en az 2 defa tura gelmesi
300 kez atıldığında en az 200 kere tura gelmesi eş olasılığa
örnektir.'cümlelerini kurmuştur.
A- Size göre öğrencinin cevabı doğru mudur? Doğru
değilse nedenini açıklayınız.
B-Size göre öğrencilerin cevabı kavram yanılgısı içerir
mi? Eğer içerdiğini düşünüyorsanız kavram yanılgısının
ne olduğunu ve nedenini açıklayınız?
C-Ĕğer kavram yanılgısı olduğunu düşünüyorsanız, bu
kavram yanılgısını düzeltmek için hangi yöntemleri
kullanırdınız?

\section{Verilerin Analizi}

Verilerin analizinde, içerik analizi ve betimsel analiz teknikleri kullanılmıştır. Literatürdeki kavram yanılgıları, Gökkurt-Özdemir, Bayraktar ve Yılmaz'ın (2017) kodlarından faydalanıldı̆̆ı için betimsel analiz, araştırmacılar tarafından oluşturulmuş kodlar kullanıldığından içerik analizi kullanılmıştır. Çalışmanın güvenirliği için pilot uygulama yapılmış, görüşme, ses kaydı ve araştırmacıların gözlem notları olmak üzere birden fazla veri toplama aracı kullanılmıştır. Yapılan kodlamanın güvenirliği için veriler iki araştırmacı tarafından yeniden kodlanmış ve kodlama yüzdesi Miles ve Huberman'ın (1994) uyuşma hesabı kullanılarak \%92 olarak bulunmuştur. Geriye kalan \%8'lik farklılık için araştırmacılar kavram yanılgıları üzerinde başka bir uzmana danışarak uzlaşmaya varmışlardır.

\section{Bulgular}

$\mathrm{Bu}$ bölümde, öğretmenlerin ve öğretmen adaylarının kavram yanılgılarına ilişkin öğretimsel açıklamalarına ilişkin bulgular, tablolar halinde sunulmuştur. Kavram yanılgılarının ne olduğu ve nedenine ilişkin bulgularla, bu yanılgıların giderilmesine ilişkin kullanılan yöntem ve teknikler iki alt başlık halinde sunulmuştur.

Öğretmenlerin ve Öğretmen Adaylarının Olasılıkla İlgili Kavram Yanılgılarına Yönelik Yaptıkları Öğretimsel Açıklamalara İlişkin Bulgular 
Tablo 3. Matematik öğretmenlerinin ve öğretmen adaylarının birinci senaryodaki kavram yanılgısına ilişkin öğretimsel açıklamalarına ait temalar ve alt temalar

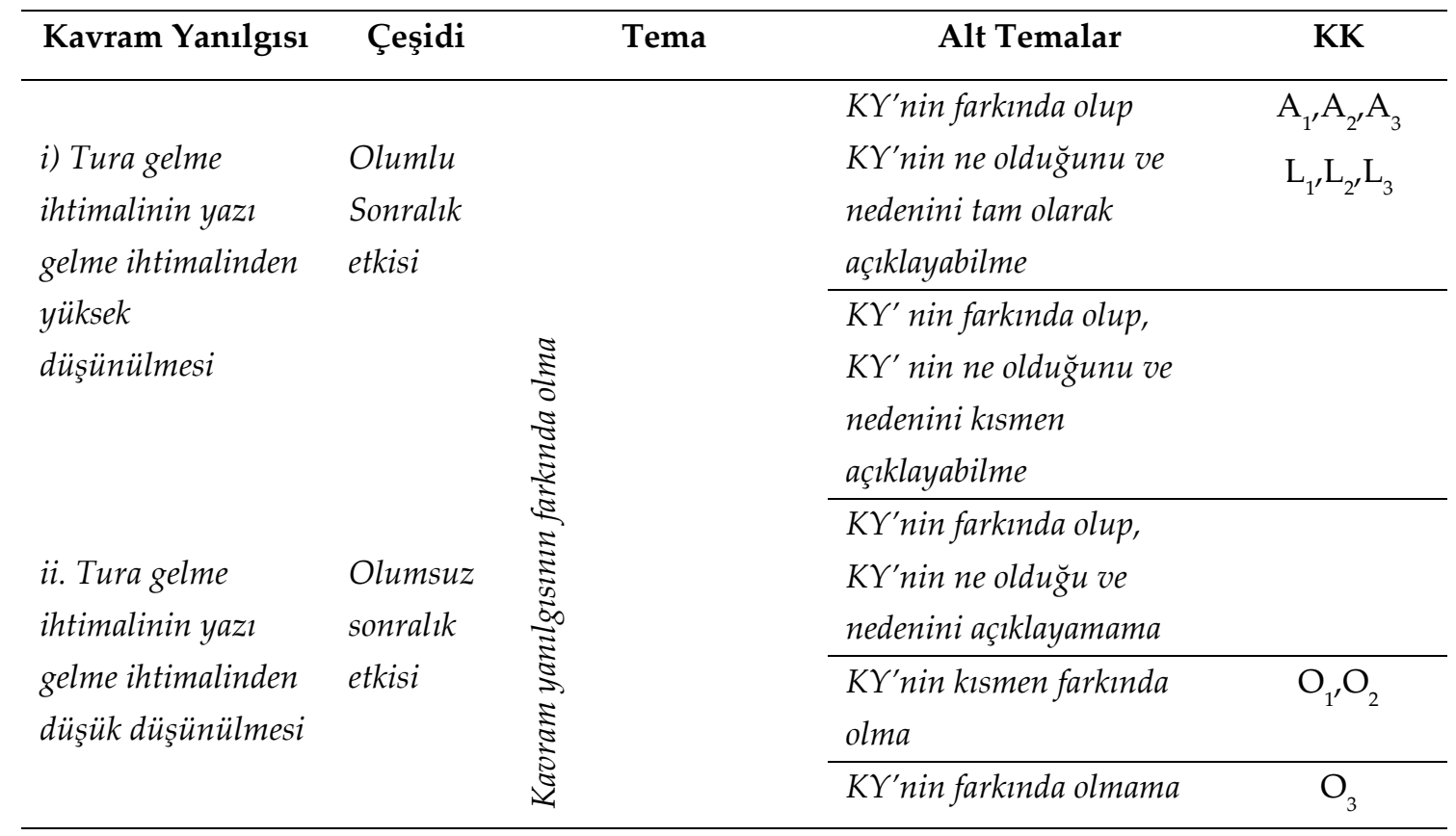

KY: Kavram Yanılgısı, KK: Katılımcı Kodları

Tablo 3 incelendiğinde adayların ve lise öğretmenlerinin tümünün birinci senaryodaki kavram yanılgılarını fark edip açıklayabildikleri ancak ortaokul öğretmenlerinin fark edemediğini ya da kısmen fark ettiği görülmektedir. Ortaokul matematik öğretmenlerinden de $\mathrm{O}_{1}$ ve $\mathrm{O}_{2}$ öğretmenlerinin olumlu ve olumsuz sonralık etkisi kavram yanılgısının kısmen fark etmelerine karşın $\mathrm{O}_{3}$ öğretmeni bu kavram yanılgısının farkında değildir. Kavram yanılgısının varlığından haberdar olan öğretmenlerden $\mathrm{A}_{1}$ in açıklaması Şekil 1'de aynen verilmiştir.

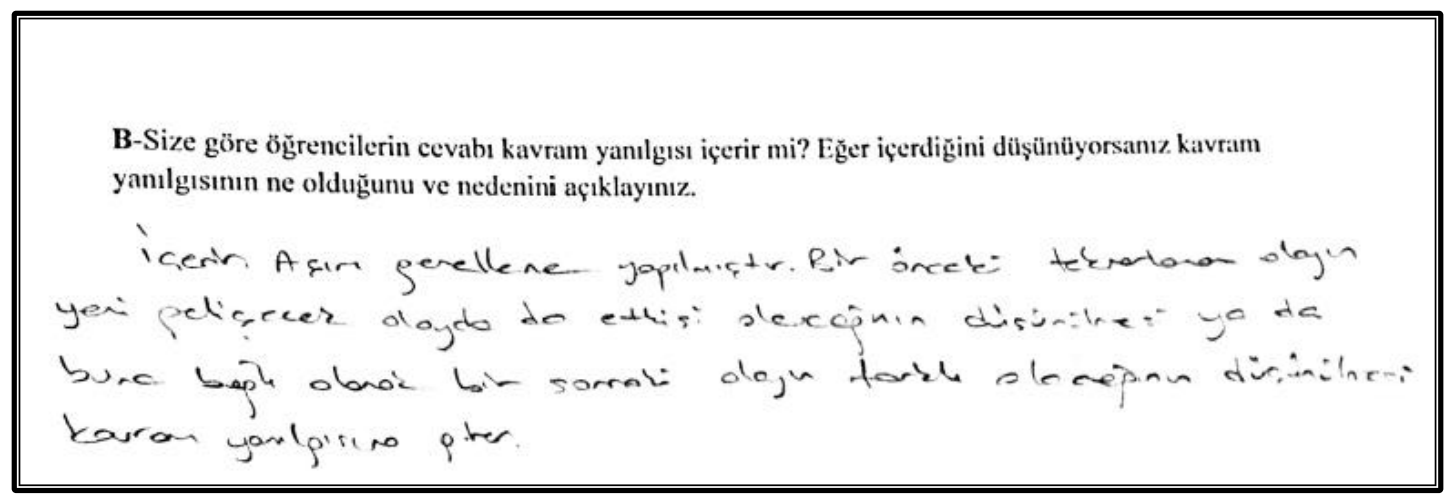

Şekil 1. A1'in birinci senaryoya ilgili doğru yazılı açılaması

A 1 öğretmeni ile yapılan görüşmede de A1, kavram yanılgısının ne olduğunu detaylı açıklamıştır. 
Araştırmacı: Yaptı̆̆ınız açıklamayı biraz daha detaylı açıklayabilir misiniz?

A1: Tabi. Ayşe ve Özge'nin her ikisi de hatalı düşünmekte ve kavram yanılgısına sahiptir. Biri 3 kez paranın tura geldiği için dördüncü atışta tura, diğeri de hiç yazı gelmediği için yazı gelme ihtimalini tura gelme ihtimalinden yüksek görmektedir. Bu durum kız ve erkek çocuğa benzetilebilir. Sürekli erkek bebek dünyaya getiren bir annenin dördüncü kez erkek bebek dünyaya getirmesini düşünmek gibi. Yani ya olumlu ya da olumsuz düşünmektedirler. Yanılgının tam olarak bilimsel ismini bilmiyorum ama bu yanılgıyı öğrencilerde görebiliyoruz...

Yukarıdaki açıklamadan anlaşılacağı üzere, öğretmen adayının doğrudan kavram yanılgısının ismini söylemese bile öğrencilerin yaptıkları yanlışların bir yanılgı olduğunun farkında olduğu ve bu yanılgının ne olduğunu açıklayabildiği görülmektedir. Tablo 3'e göre $\mathrm{O}_{2}$ öğretmeni kavram yanılgısının kısmen farkındadır. $\mathrm{O}_{2}$ öğretmeni verilen senaryoda hilesiz madeni para atışında ilk atışlarda gelen yüzün sonraki atışı etkilemesi şeklindeki kavram yanılgısına sahip olan Ayşe'nin düşüncesini doğru bulmaktadır. Buna karşın madeni para deneyinde sonraki atışta gelecek yüzün ilk atışlarda gelen yüzden farklı olacağının düşünülmesi olan olumsuzluk sonralık etkisi kavram yanılgısını fark edebilmiştir. $\mathrm{O}_{2}$ öğretmeninin olumlu sonralık etkisi kavram yanılgısını fark edememesine rağmen olumsuz sonralık etkisi kavram yanılgısını fark ettiği aşağıda verilen alıntıda örneklenmektedir.

“...Bence Ayşe'nin kavram yanılgısı bulunmamaktadır. Özge'nin kavram yanılgısı ise sonuç tekrarlandıkça diğer seçeneğin olasıllğııın artmasıdır. Sürekli tura geldiği için yazının gelmesi gerektiğini düşünmesi yanılgıya uğramasına yol açmıştır...( $\left.\mathrm{O}_{2}\right)$ "

Tablo 4. Matematik Öğretmenlerinin ve Öğretmen Adaylarının İkinci Senaryodaki Kavram Yanılgısına İlişkin Öğretimsel Açıklamalarına Ait Temalar ve Alt Temalar

\begin{tabular}{|c|c|c|c|c|}
\hline Kavram Yanılgısı & Çeşidi & Tema & Alt Temalar & KK \\
\hline $\begin{array}{l}\text { Bir madeni paranın } 3 \\
\text { kez atıldı̆̆ında en az } 2\end{array}$ & \multirow{5}{*}{$\begin{array}{c}\text { Orantı } \\
\text { lı } \\
\text { modeli } \\
n \\
\text { yanlış } \\
\text { kullanı } \\
\text { mı }\end{array}$} & \multirow{5}{*}{ 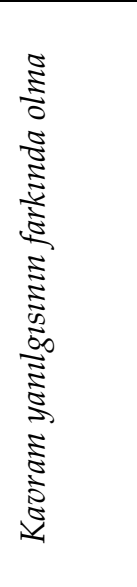 } & $\begin{array}{l}\text { KY'nin farkında olup KY'nin ne } \\
\text { olduğunu ve nedenini tam olarak } \\
\text { açılayabilme }\end{array}$ & $\begin{array}{l}\mathrm{O}_{2^{\prime}} \mathrm{A}_{1} \\
\mathrm{~L}_{1^{\prime}} \mathrm{L}_{3}\end{array}$ \\
\hline $\begin{array}{l}\text { defa tura gelmesi ile } \\
300 \text { kez atıldığında en } \\
\text { az } 200 \text { kere tura }\end{array}$ & & & $\begin{array}{l}\text { KY'nin farkında olup, KY'nin ne } \\
\text { olduğunu ve nedenini kısmen } \\
\text { açılayabilme }\end{array}$ & $\mathrm{A}_{2^{\prime}} \mathrm{L}_{2}$ \\
\hline $\begin{array}{l}\text { gelmesinin eş olasıllk } \\
\text { olarak düşünülmesi }\end{array}$ & & & $\begin{array}{l}\text { KY'nin farkında olup, KY'nin ne } \\
\text { olduğu ve nedenini açklayamama }\end{array}$ & \\
\hline (Örneklem & & & KY'nin kısmen farkında olma & $\mathrm{A}_{3}$ \\
\hline $\begin{array}{l}\text { büyüklügünün etkisi } \\
\text { yanılgısi) }\end{array}$ & & & KY'nin farkında olmama & $\mathrm{O}_{1^{\prime}} \mathrm{O}_{3}$ \\
\hline
\end{tabular}


Tablo 4 incelendiğinde dört katılımcının ikinci senaryodaki kavram yanılgısının tam olarak farkında oldukları, iki katılımcının kavram yanılgısının ne olduğunu ve nedenini tam olarak açıklayamadıkları, üç katılımcının da kavram yanılgısının farkında olmadığı veya kısmen farkında olduğu görülmektedir. Bu yanılgıda lisede çalışan öğretmenlerin, ortaokulda görev yapan öğretmenlere göre daha fazla bilgi sahibi oldukları dikkat çekicidir. $\mathrm{Bu}$ yanılgıyı bilen $\mathrm{O}_{2}$ öğretmeninin aşağıda verilen cevabı kavram yanılgısının farkında olduğunu ve açıkladığını en iyi şekilde göstermektedir.

“...Kavram yanılgısı içerir. Her iki olayı eş olasılıklı görmüşler. Madeni paranın 3 kez havaya atıldiğııda en az iki defa tura gelmesi ile 300 kere atıldı ğında 200 kere tura gelmesi $\frac{2}{3}$ ve $\frac{200}{300}$ olarak düşünülmüş. Oran yapmışlar, örneklem uzay göz önünde bulundurulmamış...( $\left.\mathrm{O}_{2}\right)$

Tablo 5'te “Gül Öğretmen bir test kitabındaki 'Hilesiz iki zar aynı anda atıldığında, üste gelen sayıların toplamının 9 ve 11 gelme olasılıkları nedir? 'sorusunu tahtaya yazmıştır. Ali 'Zar atıldığıında kaç geleceği şansa bağlıdır öğretmenim 'sayıların toplamının 9 veya 11 gelme olasılıkları eşittir.' cümlesiyle yanıtlamıştır." ifadesindeki eş olasılık yanlılığına ait kavram yanılgısıyla ilgili senaryoya ait bulgulara yer verilmiştir.

Tablo 5. Matematik öğretmenlerinin ve öğretmen adaylarının üçüncü senaryodaki kavram yanılgısına ilişkin öğretimsel açılamalarına ait temalar ve alt temalar

\begin{tabular}{|c|c|c|c|c|}
\hline Kavram Yanılgısı & Çeşidi & Tema & Alt Temalar & KK \\
\hline \multirow{8}{*}{$\begin{array}{l}\text { Bir olayın bütün } \\
\text { çıktılarının eşit } \\
\text { olasılıklı görmeye } \\
\text { eğilimli olma } \\
\text { durumu }\end{array}$} & \multirow{8}{*}{$\begin{array}{c}\text { Eş } \\
\text { Olasılık } \\
\text { Yanlılığı }\end{array}$} & \multirow{8}{*}{ 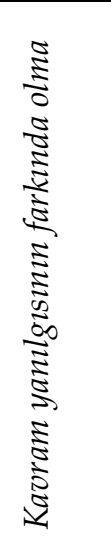 } & $\begin{array}{l}\text { KY'nin farkında olup KY'nin ne } \\
\text { olduğunu ve nedenini tam olarak } \\
\text { açıklayabilme }\end{array}$ & $\mathrm{A}_{2^{\prime}} \mathrm{L}_{3}$ \\
\hline & & & KY'nin farkında olup, KY'nin ne & $\mathrm{A}_{1}, \mathrm{O}_{1}$ \\
\hline & & & olduğunu ve nedenini kısmen & $\mathrm{O}$ \\
\hline & & & açıklayabilme & \\
\hline & & & KY'nin farkında olup, KY'nin ne & \\
\hline & & & olduğu ve nedenini açıklayamama & \\
\hline & & & KY'nin kısmen farkında olma & \\
\hline & & & KY'nin farkında olmama & $\mathrm{O}_{3^{\prime}} \mathrm{A}_{3^{\prime}} \mathrm{L}_{2}$ \\
\hline
\end{tabular}

Tablo 5 incelendiğinde, dokuz katılımcıdan altısının üçüncü senaryodaki kavram yanılgısının farkında oldukları ancak üç katılımcının kavram yanılgısının farkında olmadıkları görülmektedir. Öğretmenlerden $\mathrm{O}_{1}$ kavram yanılgısının farkında olup, iki zar 
atıldığında üste gelen sayıların toplamının 9 gelme olasılığıyla 11 gelme olasılığının eşit olmadığını belirtmiş ancak bu kavram yanılgısının altında yatan mantıksal gerekçeyi tam olarak ifade edememiştir. Aşağıda verilen alıntısı bunu açıkça göstermektedir.

“... Soruda öğrenci iki zar atıldı̆̆ında üste gelen sayıların toplamının 9 gelme ihtimali ile 11 gelme ihtimalini eşit düşünmüştür. Öğrencinin cevabı kavram yanılgısı içerir. İki zar atıldığgında üste gelen sayıların toplamının 9 olma olasılığı $\frac{1}{9}$ ve 11 gelme olasılığı ise $\frac{1}{18}$ 'dir. Öğrenci ise 9 ve 11 gelme olasılıklarını eşit olarak düşünmüşler. Bilgiyi yanlış kullanmış, teorik ve deneysel olasılığı karıştırmış herhalde. Neden bu şekilde düşünmüş olabilir anlayamadım...( $\left.\mathrm{O}_{1}\right)^{\prime \prime}$

$\mathrm{Bu}$ açıklamaya bakıldığında $\mathrm{O}_{1}$ öğretmeni senaryodaki durumda kavram yanılgısı olduğunu fark etmiş, gerekli hesaplamaları yaparak cevaptaki yanlışlı̆̆ı da dile getirmiştir. Katılımcı senaryodaki öğrencinin 9 gelme olasılığıyla 11 gelme olasılığını eş olasılıklı düşündüğünü fark edebilmesine rağmen, yanılgının nedenini tam olarak ifade edememiştir. Burada öğrenci hilesiz bir zar atıldığında bütün çıktıların eşit olma olasılığı ile karıştırmıştır. Öğrenci zarların kombinasyonlarının da eşit olacağını düşünerek kavram yanılgısına düşmüştür. Öğrencinin bir zarda olduğu gibi eş olasılı olma varsayımını, eş olasılı olmayan iki zarın toplamlarının dağılımı gibi durumlara genelleyerek aşırı genelleme eğiliminde olduğu açıkça görülmektedir.

Tablo 6' da “Ayşe Öğretmen olasılık konusunu anlatırken, yapılan bir anket araştırmasını sınıfla paylaşmış ve öğrencilerin tahminlerini almıştır.

Tüm yaş gruplarından ve mesleklerden Avusturalya'lı erkekler arasında 100 kişilik bir örnekleme, bir sağlık anketi uygulanmıştır.

a-100 erkekten kaçı 1 ya da daha fazla kalp krizi geçirmiş olabilir. Tahmin ediniz?

b- 100 erkekten kaçı 55 yaş üzeri olabilir. Tahmin ediniz?

c-100 erkekten kaçı hem 55 yaş üzeri hem de 1 ya da daha fazla kalp krizi geçirmiş olabilir. Tahmin ediniz?

Ayşe Öğretmenin bu sorusuna karşılık öğrencilerinin çoğu, c şıkkının olasılığını a ve b şıklarındaki olasıllktan daha yüksek olarak tahmin etmişlerdir." ifadesindeki birleşim yanılgısına ait kavram yanılgısıyla ilgili senaryoya ait bulgulara yer verilmiştir. 
Tablo 6. Matematik öğretmenlerinin ve öğretmen adaylarının dördüncü senaryodaki kavram yanılgısına ilişkin öğretimsel açıklamalarına ait temalar ve alt temalar

\begin{tabular}{|c|c|c|c|c|}
\hline Kavram Yanılgısı & Çeşidi & Tema & Alt Temalar & KK \\
\hline \multirow{5}{*}{$\begin{array}{l}\text { İki olayın birlikte } \\
\text { gerçekleşme olasılığı } \\
\text { bu olayların ayrı } \\
\text { ayrı gerçekleşme } \\
\text { olasılığından daha } \\
\text { yüksek olduğunun } \\
\text { düşünülmesi }\end{array}$} & \multirow{5}{*}{$\begin{array}{l}\text { Birleşim } \\
\text { yanılgısı }\end{array}$} & \multirow{5}{*}{ 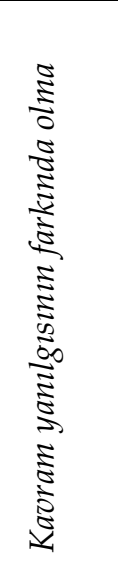 } & $\begin{array}{l}\text { KY'nin farkında olup KY'nin ne } \\
\text { olduğunu ve nedenini tam olarak } \\
\text { açılayabilme }\end{array}$ & $\begin{array}{c}\mathrm{O}_{2^{\prime}} \mathrm{A}_{1^{\prime}} \mathrm{L}_{1} \\
\mathrm{~L}_{3}\end{array}$ \\
\hline & & & $\begin{array}{l}\text { KY'nin farkında olup, KY'nin ne } \\
\text { olduğunu ve nedenini kısmen } \\
\text { açıklayabilme }\end{array}$ & $\mathrm{O}_{1}, \mathrm{O}_{3}$ \\
\hline & & & $\begin{array}{l}\text { KY'nin farkında olup, KY'nin ne olduğ } u \\
\text { ve nedenini açılayamama }\end{array}$ & \\
\hline & & & KY'nin kısmen farkında olma & $\mathrm{A}_{3^{\prime}} \mathrm{L}_{2}$ \\
\hline & & & KY'nin farkında olmama & $\mathrm{A}_{2}$ \\
\hline
\end{tabular}

Tablo 6 incelendiğinde, dördüncü senaryodaki kavram yanılgısı hakkında altı katılımcının farkında olduğu, ikisinin kısmen farkında olduğu ve bir öğretmen adayının ise kavram yanılgısının farkında olmadığı görülmektedir. Öğretmen adaylarının diğer yanılgılara kıyasla bu yanılgıyı tespit etmekte zorlandıkları görülmektedir. Öğretmen adayı olan $\mathrm{A}_{2}$ senaryodaki kavram yanılgısını tespit edememiş ve durumun doğru olduğunu ifade etmiştir. Bununla ilgili olarak $\mathrm{A}_{2}$ 'nin açıklaması aşağıda verilmiştir.

“...Burada kavram yanılgısı yok bence. Öğrencilerin tahmini doğru...( $\left.A_{2}\right)$ "

Bu açıklamaya bağlı olarak katılımcının senaryodaki birleşim yanılgısı olan iki ayrı olayın birleşiminin olasılığının yüksek olduğunu düşünmesi, bu yanılgının kendisinde de olduğunu açıkça göstermektedir. Diğer taraftan beş öğretmen ve bir öğretmen adayının senaryodaki kavram yanılgısını fark ederek tam veya kısmen olarak açıladıkları görülmektedir. Bununla ilgili olarak A1 'in yazılı açıklaması Şekil 2' de aynen verilmiştir.

B-Size göre öğrencilerin cevabı kavram yanılgısı içerir mi? Eğer içerdiğini düşünüyorsanız kavram yanılgısının ne olduğunu ve nedenini açıklayınız.

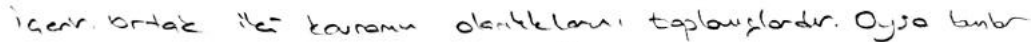

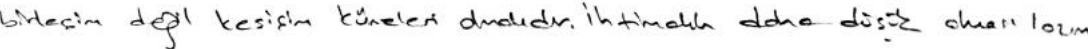

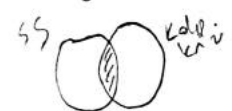

Şekil 2. Aı'in Dördüncü Senaryoya İlgili Doğru Yazılı Açıklaması 
Şekil 2 ‘ye bakıldı̆̆ında $A_{1}$ 'in farkında olduğu söylenebilir. A1'in birleşim yanılgısında iki olayın birleşme yanılgısında ihtimalin daha düşük olacağını belirterek kavram yanılgısını açıkladığı görülmektedir. Senaryoda ise ihtimalin kesişiminin alınması yerine olasılıkların toplandığını belirterek kavram yanılgısının sebebini de belirtmiştir. Yapılan görüşmede de öğrencinin iki ayrı olayın aynı anda olma olasılığını, olayların her birinin ayrı ayrı gerçekleşmesi olasılığından daha yüksek olacağını düşünerek yanılgıya düştüğünü açıkça belirtmiştir. Tablo 7'de “Fatma öğretmen sınıfa 'Hilesiz 2 zar atıldığııda zarların toplamının 6 gelme olasıliğ̆ nedir? 'sorusunu yöneltmiştir ve öğrencilere çözümlerini deftere yapmalarını istemiştir. Öğrencilerin cevapların kontrol eden Fatma Öğretmen öğrencilerin çoğunun örneklem uzayının sayısını $12(6+6)$ aldıkların fark etmiştir." ifadesindeki basit ve bileşik olay kavram yanılgısıyla ilgili senaryoya ait bulgulara yer verilmiştir.

Tablo 7. Matematik öğretmenlerinin ve öğretmen adaylarının beşinci senaryodaki kavram yanılgısına ilişkin öğretimsel açıklamalarına ait temalar ve alt temalar

\begin{tabular}{|c|c|c|c|c|}
\hline Kavram Yanılgisı & Çeşidi & Tema & Alt Temalar & KK \\
\hline \multirow{5}{*}{$\begin{array}{l}\text { Basit ve bileşik } \\
\text { olaylarda örneklem } \\
\text { uzayının eleman } \\
\text { sayısının yanlış } \\
\text { alınması }\end{array}$} & \multirow{5}{*}{$\begin{array}{c}\text { Basit } \\
\text { ve } \\
\text { bileşik } \\
\text { olay }\end{array}$} & \multirow{5}{*}{ 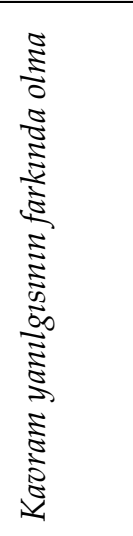 } & $\begin{array}{l}\text { KY'nin farkında olup KY'nin ne olduğunu ve } \\
\text { nedenini tam olarak açıklayabilme }\end{array}$ & $\begin{array}{c}\mathrm{O}_{2^{\prime}} \mathrm{A}_{2} \\
\mathrm{~A}_{3^{\prime}} \mathrm{L}_{1^{\prime}} \mathrm{L}_{2} \\
\mathrm{~L}_{3}\end{array}$ \\
\hline & & & $\begin{array}{l}\text { KY'nin farkında olup, KY'nin ne olduğunu ve } \\
\text { nedenini kısmen açılayabilme }\end{array}$ & $\mathrm{O}_{1}, \mathrm{~A}_{1}$ \\
\hline & & & $\begin{array}{l}\text { KY'nin farkında olup, KY'nin ne olduğu ve } \\
\text { nedenini açılayamama }\end{array}$ & \\
\hline & & & KY'nin kısmen farkında olma & \\
\hline & & & KY'nin farkında olmama & $\mathrm{O}_{3}$ \\
\hline
\end{tabular}

Tablo 7 incelendiğinde $\mathrm{O}_{3}$ öğretmeni hariç tüm aday ve öğretmenlerin kavram yanılgısının farkında oldukları ancak bir öğretmen ve bir öğretmen adayının kavram yanılgısının farkında olsalar da tam açıklama yapamadıkları görülmektedir. Bununla ilgili olarak $\mathrm{O}_{1}$ 'in açıklaması aşağıda verilmiştir. 


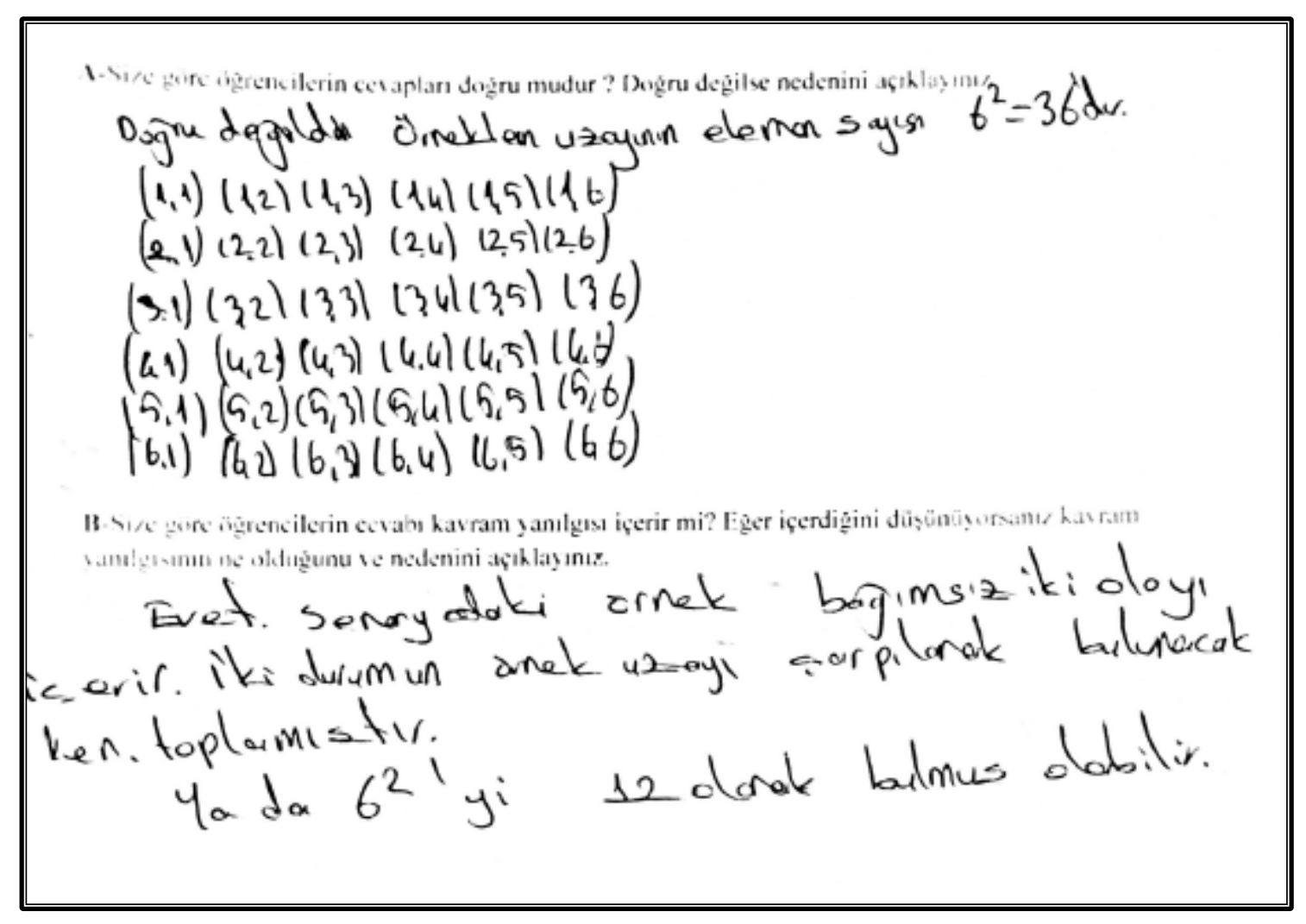

Şekil 3. $\mathrm{O}_{1}^{\prime}$ in altıncı senaryoya ilişkin yazılı açıklaması

Şekil 3’te görüldü̆ğü üzere, $\mathrm{O}_{1}$ kavram yanılgısının farkında olup, bu yanılgının ne olduğunu açıklayabilmiştir. Ancak nedenini tam olarak açıklayamamıştır. $\mathrm{O}_{1}$ ile yapılan görüşmede, $\mathrm{O}_{1}$ öğrencinin örneklem uzayını yanlış hesapladı̆̆ını dile getirmiştir. Ancak öğrencinin bileşik olaylar ard arda veya birlikte meydana geldiğinde, örneklem uzayını hesaplayamadığını kısaca bileşik olayların örneklem uzayını belirlemede sıkıntı yaşadığını dile getirememiştir. Katılımcının ikinci alternatif olarak öğrencinin doğru çözüm yapıp $6^{2}$ ifadesinde üslü ifadeyi hesaplarken 6×2 şeklinde hesaplayarak yanılgının üslü ifadeleri anlayamadığından kaynaklanmış olabileceğini belirtmesi, açılamasının kısmen yeterli alt temasında değerlendirilmesine neden olmuştur.

Tablo 8' de “Olasılık konusunu işledikten sonra Mustafa öğretmen sınıfa bir test kâğı̆dı dağıtmıştır. Bu testte yer alan sorulardan ikisi şu şekildedir:

1.Soru; Hilesiz madeni bir para havaya 5 kez atıldı̆̆ında aşă̆ıdaki sonuçlardan hangisinin olma olasılığı en yüksektir? (T=TURA, Y=YAZI)
A-T T TYY
$B-Y T T Y T$
C-YTYYY
$D-T Y T Y T$
E-hepsi eş olasılı

2.soruda ise soruyu tersten sormuştur; 
Hilesiz madeni bir para havaya 5 kez atıldığında aşă̆ıdaki sonuçlardan hangisinin olma olasılı̆̆ı en düşüktür? (T=TURA, Y=YAZI)
$A-T T T Y Y$
$B-Y T T Y T$
C-YTYYY
$D-T Y T Y T$
E-hepsi eş olasılı

Cevapları inceleyen Mustafa Öğretmen 1.soruya öğrencilerin büyük çoğunluğunun(\%72) 'Ehepsi eş olasılı' seçeneğini seçtiğini fakat soruyu tersten sordŭ̆u 2.soruda öğrencilerin bir kısmının (\%38) 'E-hepsi eş olasılı' seçeneğini seçtiğinin fark etmiştir." ifadesinde sonuç yaklaşımı kavram yanılgısıyla ilgili senaryoya ait bulgulara yer verilmiştir.

Tablo 8. Matematik öğretmenlerinin ve öğretmen adaylarının altıncı senaryodaki kavram yanılgısına ilişkin öğretimsel açılamalarına ait temalar ve alt temalar

\begin{tabular}{|c|c|c|c|c|}
\hline Kavram Yanılgısı & Çeşidi & Tema & Alt Temalar & KK \\
\hline \multirow{5}{*}{$\begin{array}{l}\text { Bir olayın olma } \\
\text { olasılığını tahmin } \\
\text { etmek yerine, } \\
\text { olayın kesinliği için } \\
\text { yorum yapmaya ve } \\
\text { karar vermeye } \\
\text { çalışmak }\end{array}$} & \multirow{5}{*}{$\begin{array}{c}\text { Sonuç } \\
\text { Yaklaşımı }\end{array}$} & \multirow{5}{*}{ 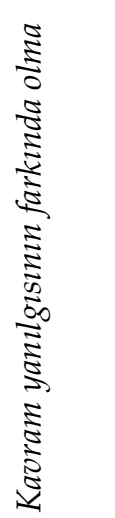 } & $\begin{array}{l}\text { KY'nin farkında olup KY'nin ne olduğunu ve } \\
\text { nedenini tam olarak açılayabilme }\end{array}$ & \\
\hline & & & $\begin{array}{l}\text { KY'nin farkında olup, KY'nin ne olduğunu ve } \\
\text { nedenini kısmen açıklayabilme }\end{array}$ & $\mathrm{A}_{2^{\prime}} \mathrm{L}_{2}, \mathrm{O}_{1}$ \\
\hline & & & $\begin{array}{l}\text { KY'nin farkında olup, KY'nin ne olduğu ve } \\
\text { nedenini açılayamama }\end{array}$ & $\mathrm{A}_{1}$ \\
\hline & & & KY'nin kısmen farkında olma & $\mathrm{O}_{3}$ \\
\hline & & & KY'nin farkında olmama & $\begin{array}{c}\mathrm{O}_{2^{\prime}} \mathrm{A}_{3^{\prime}} \mathrm{L}_{1} \\
\mathrm{~L}_{3}\end{array}$ \\
\hline
\end{tabular}

Tablo 8 incelendiğinde, öğretmenlerin ve öğretmen adaylarının bu yanılgının ne olduğunu ve nedenini açıklamada diğer yanılgılara kıyasla zorlandıkları ve hiçbirinin istenilen şekilde tam olarak doğru açıklamada bulunamadıkları görülmüştür. Tablo 8'deki bulgulara göre, bir aday ve dört öğretmen sonuç yaklaşımına ilişkin kavram yanılgısının farkında değildir. Kavram yanılgısını fark edemeyen $\mathrm{L}_{1}$ ile yapılan görüşme diyalogu aşağıda verilmiştir.

Araştırmacı:Sizce öğrencilerin farklı düşünmelerinin sebebi ne olabilir?

$L_{1}: .$. Öğrenciler birbirinden etkilenmiş olduğunu düşünüyorum...

Araştırmacı:Sizce kavram yanılgısı içerir mi?

$L_{1}:$ Kavram yanılgısı görmüyorum.

Bu diyalogdan da anlaşıldığı üzere $L_{1}$ öğretmeni sonuç yaklaşımı kavram yanılgısının varlığını fark edemediği söylenebilir. Kısmen yeterli cevabını veren $A_{2}$ öğretmen adayının açıklamalarını içeren diyalog aşağıda verilmiştir. 
Araştırmacl: Size göre öğrencilerin farklı düşünme sebepleri nedir?

$A_{2} \ldots$ Öğrencilere soru tersten sorulduğunda şıkların hepsinin eş olasılıklı düşünmelerinin oranı azalmış... Olma olasılı̆̆ı en yüksek sonuç sorulduğunda hepsi eş olasılıklı cevabını verme oranı olma olasılığı en düşük sonuç soruldŭ̆unda düşmüş, sonuçların farklı olduğunu düşünmüşler. Sonuçların hepsinin eş olasılıklı olduğunu düşünmedikleri için kavram yanılgısına düşmüşlerdir. Nedeni sorunun tersten sorulması olabilir...

$\mathrm{A}_{2}^{\prime}$ nin açıklamasına bakılarak senaryodaki kavram yanılgısının farkında olduğu, öğrencilere soru tersten sorulduğunda kavram yanılgısına düştükleri ve eş olasılığ belirleyemedikleri, en yüksek ve en düşük kelimelerinden dolayı sonuca odaklandıkları şeklindeki ifadelerinin doğru olduğu söylenebilir. Adaydan tam olarak istenilen açıklama, yanılgının nedeninin sonuç yaklaşımına bağlamasıydı. Konold ve diğerleri (1993), bu yanılgının sebebini, öğrencilerin en yüksek olasılıklı sonucunu soran sorudan en düşük olasılıklıyı soran soruya geçildiğinde, cevaplarının değişmesinde öğrencilerin bakış açısının sonuç yaklaşımından temsil kısayoluna değişmesi olarak ifade etmişlerdir. Diğer bir ifadeyle doğru yanıtın her iki soruda aynı olmasına rağmen, yanıtlardaki bu tutarsızlığın öğrenciler için bir çelişki olarak görülmemesidir.

Tablo 9' da “Olasılık konusunu anlattıktan sonra yazılı da bu konunun öğrenilme durumunu ölçmek isteyen Özlem Öğretmen yazılıda 'Ayrık olay nedir, tanımlayınız ve bir örnekle açıklayınız.' sorusunu sormuştur.

Yazılı kâğıtlarını inceleyen öğretmen şöyle yanıtlara rastlamıştır:

'Gerçekleşmeleri birbirini etkilemeyen olaylar ayrık olaylardır. Mesela, para ve bir zar aynı anda atılırsa bunlar birbirini etkilemez, ayrik olay olurlar.'

'Olaylar birbirini etkilemezse ayrı olay olur. Torbadan top çekersem ve bir parayı havaya atarsam bunlar ayrık olaylardır." ifadesinde ayrık olaylarla bağımsız olayların birbirine karıştırılmasına ilişkin kavram yanılgısıyla ilgili senaryoya ait bulgulara yer verilmiştir. 
Tablo 9. Matematik öğretmenlerinin ve öğretmen adaylarının yedinci senaryodaki kavram yanılgısına ilişkin öğretimsel açıklamalarına ait temalar ve alt temalar

\begin{tabular}{|c|c|c|c|c|}
\hline $\begin{array}{l}\text { Kavram } \\
\text { Yanılgısı }\end{array}$ & Çeşidi & Tema & Alt Temalar & KK \\
\hline \multirow{5}{*}{$\begin{array}{l}\text { Bağımsız } \\
\text { olaylar ile ayrık } \\
\text { olayları } \\
\text { birbirine } \\
\text { karıştırılması }\end{array}$} & \multirow{5}{*}{$\begin{array}{l}\text { Ayrık ve } \\
\text { bağımsız } \\
\text { olaylar }\end{array}$} & \multirow{5}{*}{ 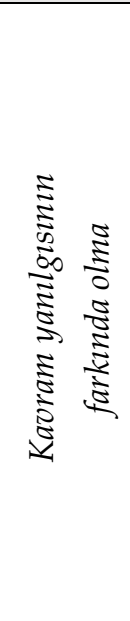 } & $\begin{array}{l}\text { KY'nin farkında olup KY'nin ne } \\
\text { olduğunu ve nedenini tam olarak } \\
\text { açılayabilme }\end{array}$ & $\mathrm{L}_{2}$ \\
\hline & & & $\begin{array}{l}\text { KY'nin farkında olup, KY'nin ne } \\
\text { olduğunu ve nedenini kısmen } \\
\text { açılayabilme }\end{array}$ & $\mathrm{O}_{1^{\prime}} \mathrm{O}_{3^{\prime}} \mathrm{L}_{1}$ \\
\hline & & & $\begin{array}{l}\text { KY'nin farkında olup, KY'nin ne olduğu } \\
\text { ve nedenini açılayamama }\end{array}$ & \\
\hline & & & KY'nin kısmen farkında olma & \\
\hline & & & KY'nin farkında olmama & $\begin{array}{l}\mathrm{O}_{2^{\prime}} \mathrm{A}_{1^{\prime}} \\
\mathrm{A}_{2^{\prime}}, \mathrm{A}_{3^{\prime}} \mathrm{L}_{3}\end{array}$ \\
\hline
\end{tabular}

Tablo 9 incelendiğinde görüşme yapılan tüm öğretmen adaylarının ve iki öğretmenin kavram yanılgısının farkında olmadıkları buna karşın geriye kalanların kavram yanılgısının farkında oldukları ancak sadece $\mathrm{L}_{2}$ öğretmeninin bu yanılgıyı tam olarak ifade edebildiği görülmektedir. Bununla ilgili olarak $\mathrm{L}_{2}$ 'nin yazılı açıklaması Şekil 4'te aynen verilmiştir.

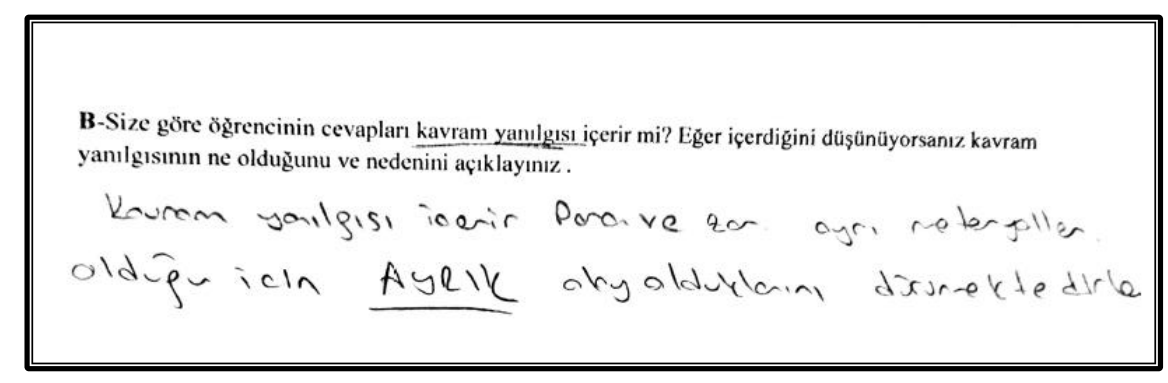

Şekil 4. $L_{2}$ 'nin yedinci senaryoya ilişkin yazılı açıklaması

Şekil 4'te katılımcının yazılı açıklaması eksik olsa da yapılan görüşmede $\mathrm{L}_{2}$ 'nin kavram yanılgısının ne olduğunu ve nedenini tam olarak açıklayabilmiştir. $\mathrm{L}_{2}$ öğretmeni görüşmede bu ifadede bahsedilen durumun bağımsız olaylar olduğunu, ayrık olaylar ile bağımsız olayların birbirine karıştırılmış olduğunu ifade etmiştir. $\mathrm{L}_{2^{\prime}}$ ayrık olayları aynı anda gerçekleşme olasılığı olmayan ve kesişimleri boş küme olan olaylar olarak doğru dile getirmiştir. Ayrıca para atılmasında ortaya çıkan sonucun olup ya da olmamasının, zar atılma olayını etkilemediğini dile getirerek aslında verilen olayların bağımsız olaylara ait olduğunu belirtmiştir. 
Tablo 10'da “Sultan Öğretmen olasıllk konusunu anlattıktan sonra tahtaya bir soru yazar ve öğrencilerin tahminlerini sorar: Hilesiz bir para havaya atılıyor. Hangisi şıkkın gerçekleşme olasılı̆̆ı yüksektir?
A)TYTYTYTYTY
B) TTTTTTTTTY
C) YTYYYTTYTT
D) TTYYTTYYTT

Esra cevap hakkı alır ve "Hocam, A şıkkının gerçekleşmesi çok zor, sırayla yazı tura yazı tura gelmesi pek mümkün olmaz bence" der.

Mehmet parmak kaldırır ve "Bence de B şıkkının olması çok zor, sürekli tura gelmiş" der Muhammed söz hakkı alır ve "Hocam c şıkkının gerçekleşmesi yüksektir" der.

Son olarak Ayşe cevap hakkı alır ve "Hocam hepsi de eşit ihtimalli bence" diye cevap verir."

ifadesinde temsil kısa yoluna ilişkin kavram yanılgısıyla ilgili senaryoya ait bulgulara yer verilmiştir.

Tablo 10. Matematik öğretmenlerinin ve öğretmen adaylarının sekizinci senaryodaki kavram yanılgısına ilişkin öğretimsel açklamalarına ait temalar ve alt temalar

\begin{tabular}{|c|c|c|c|c|}
\hline $\begin{array}{l}\text { Kavram } \\
\text { Yanılgısı }\end{array}$ & Çeşidi & Tema & Alt Temalar & KK \\
\hline \multirow{5}{*}{$\begin{array}{l}\text { Bir olayın olma } \\
\text { olasılığının, o } \\
\text { olayı örneklem } \\
\text { uzayını ne kadar } \\
\text { iyi yansıttı̆̆ına } \\
\text { göre } \\
\text { değerlendirilme } \\
\text { durumudur }\end{array}$} & \multirow{5}{*}{$\begin{array}{c}\text { Temsil } \\
\text { kısa } \\
\text { yolu }\end{array}$} & \multirow{5}{*}{ 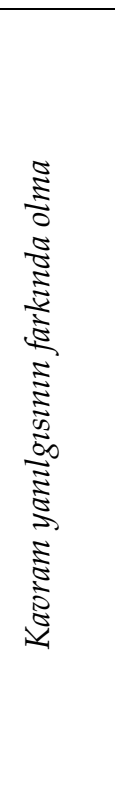 } & $\begin{array}{l}\text { KY'nin farkında olup } \\
\text { KY'nin ne olduğunu ve } \\
\text { nedenini tam olarak } \\
\text { açıklayabilme }\end{array}$ & $\mathrm{A}_{2}$ \\
\hline & & & $\begin{array}{l}\text { KY'nin farkında olup, } \\
\text { KY'nin ne olduğunu ve } \\
\text { nedenini kısmen } \\
\text { açıklayabilme }\end{array}$ & $\begin{array}{c}\mathrm{L}_{1^{\prime}} \mathrm{L}_{3^{\prime}} \mathrm{A}_{1^{\prime}} \\
\mathrm{A}_{3}\end{array}$ \\
\hline & & & $\begin{array}{l}\text { KY'nin farkında olup, } \\
\text { KY'nin ne olduğu ve } \\
\text { nedenini açıklayamama }\end{array}$ & \\
\hline & & & $\begin{array}{l}\text { KY'nin kısmen farkında } \\
\text { olma }\end{array}$ & $\begin{array}{c}\mathrm{O}_{1^{\prime}} \mathrm{O}_{2^{\prime}} \mathrm{O}_{3^{\prime}} \\
\mathrm{L}_{2}\end{array}$ \\
\hline & & & KY'nin farkında olmama & \\
\hline
\end{tabular}

Tablo 10`a bakıldığında ortaokul matematik öğretmenlerinin ve bir lise matematik öğretmeninin belirtilen kavram yanılgısının kısmen farkında olduğu görülmektedir. Buna karşın iki lise matematik öğretmeni ve üç matematik öğretmeni adayının kavram 
yanılgısının farkında olduğu ve sadece $A_{2}$ adayının kavram yanılgısını ve nedenini tam olarak açıklayabildiği görülmektedir. $A_{2}^{\prime}$ nin açıklaması aşağıda verilmiştir.

“...Öğrencilerden sadece Ayşe'nin cevabı doğrudur, diğgrlerinin cevabı yanlıştır. Para için yazı ve tura gelme olasılığı eşittir. Ayşe hariç diğgerlerinin cevabı kavram yanılgısı içerir. Bu öğrenciler sonuçları YTYTYT... veya TTTTTTY şeklinde sıralı gelmesinin gerçek atışlarda gelmeyeceğini düşünüyorlar. Örneğin Esra, TYTYTYTYTY sıralamasını çok düzenli bulduğu için daha az rastgele algilamakta, bu sıralamanın yazı-tura gelme sürecini temsil edemediğini düşünmektedir ..."

$\mathrm{A}_{2}^{\prime}$ nin açıklamasında öğrencilerin sıralı cevapların gerçek hayatı temsil etmeyeceğini düşünmelerinden dolayı kavram yanılgısına sahip olduğunu belirtmesinden dolayı bu kavram yanılgısının farkında olduğu ve doğru açıklamalarda bulunduğu söylenebilir. Tablo 10'a bakıldığında $A_{1}$ öğretmen adayının kavram yanılgısının farkında olduğu ancak açıklamasının yeterli olmadığı görülmektedir. Bununla ilgili olarak $\mathrm{A}_{1}^{\prime}$ in açıklaması Şekil 5'te verilmiştir.

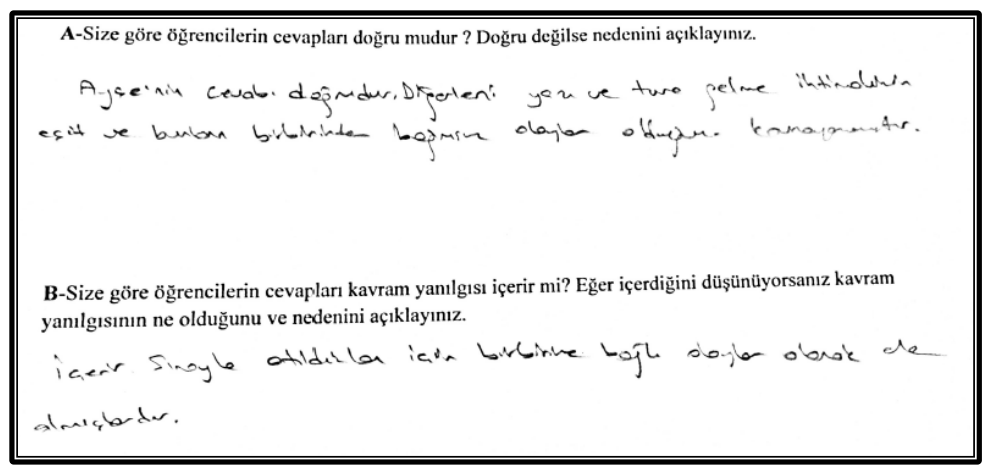

Şekil 5. A 'in sekizinci senaryo ile ilgili açıklaması

$A_{1}$ öğretmen adayı açıklamasında sadece Ayşe'nin cevabının doğru olduğunu, diğer öğrencilerin yazı ve tura gelme ihtimallerinin eşit olduğunu kavrayamadıklarını ve cevapların kavram yanılgısı içerdiğini belirttiğinden kavram yanılgısının farkında olduğu düşünülmüştür. Ancak açıklamasından kavram yanılgısının sebebi olarak birbirine bağlı olaylar olarak ele alınmasından kaynaklandığını belirtmiş ancak temsil kısa yolu kavram yanılgısına ilişkin istenilen şekilde açıklama yapamamıştır.

Tablo 11'de “Fatih Öğretmen öğrencilere koşullu olasılık konusunu anlattıktan sonra aşă̆ıdaki örneği tahtaya yazmıştır.

'Bir torbada iki beyaz, iki siyah bilye vardır. İki bilye ard arda, birincisi geri konulmadan çekilir. 
a)Birinci bilyenin beyaz olduğ u bilindiğine göre, ikinci bilyenin de beyaz olma olasılĭğ nedir?

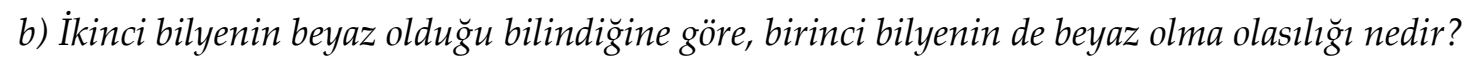

Öğrencilerin deftere çözüm yapmaların istemiş ve çoğu öğrencinin a maddesinin sonucunu $\frac{1}{3}$ olarak ve b maddesinin de sonucunu $\frac{1}{2}$ olarak hesapladıklarını görmüştür." ifadesinde koşullu olasıllı̆̆a ilişkin kavram yanılgısıyla ilgili senaryoya ait bulgulara yer verilmiştir.

Tablo 11. Matematik öğretmenlerinin ve öğretmen adaylarının dokuzuncu senaryodaki kavram yanılgısına ilişkin öğretimsel açıklamalarına ait temalar ve alt temalar

\begin{tabular}{|c|c|c|c|c|}
\hline Kavram Yanılgısı & Çeşidi & Tema & Alt Temalar & KK \\
\hline \multirow{5}{*}{$\begin{array}{l}\text { İkinci olayın } \\
\text { sonucunun } \frac{1}{3} \\
\text { olarak } \\
\text { belirlenememesi }\end{array}$} & \multirow{5}{*}{$\begin{array}{l}\text { Koşullu } \\
\text { olasılık }\end{array}$} & \multirow{5}{*}{ 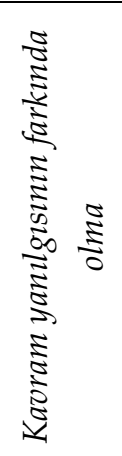 } & $\begin{array}{l}\text { KY'nin farkında olup KY'nin ne olduğunu ve } \\
\text { nedenini tam olarak açıklayabilme }\end{array}$ & \\
\hline & & & $\begin{array}{l}\text { KY'nin farkında olup, KY'nin ne olduğunu ve } \\
\text { nedenini kısmen açıklayabilme }\end{array}$ & $\mathrm{A}_{3^{\prime}} \mathrm{L}_{1^{\prime}} \mathrm{L}_{3}$ \\
\hline & & & $\begin{array}{l}\text { KY'nin farkında olup, KY'nin ne olduğu ve } \\
\text { nedenini açılayamama }\end{array}$ & $\mathrm{O}_{2}, \mathrm{O}_{3}$ \\
\hline & & & KY'nin kısmen farkında olma & $\mathrm{O}_{1}, \mathrm{~L}_{2}$ \\
\hline & & & KY'nin farkında olmama & $\mathrm{A}_{1}, \mathrm{~A}_{2}$ \\
\hline
\end{tabular}

Tablo 11'e bakıldığında iki matematik öğretmeninin belirtilen kavram yanılgısının kısmen farkında oldukları, iki öğretmen adayının ise kavram yanılgısının tamamen farkında olmadıkları görülmüştür. İki ortaokul matematik öğretmeninin ise kavram yanılgısının farkında olsalar da açıklayamadıkları, $\mathrm{A}_{3}$ adayı ve iki lise matematik öğretmeninin kavram yanılgısının farkında oldukları ancak kısmen açıklamada bulundukları görülmektedir. Buna karşın hiçbir matematik öğretmeni ve matematik öğretmeni adayının bu kavram yanılgısının farkında olup, bu yanılgının ne olduğunu ve nedenini tam olarak açıklayamadığı görülmektedir. Bununla ilgili olarak $A_{3}^{\prime}$ ün yazılı açıklaması Şekil 6'da verilmiştir.

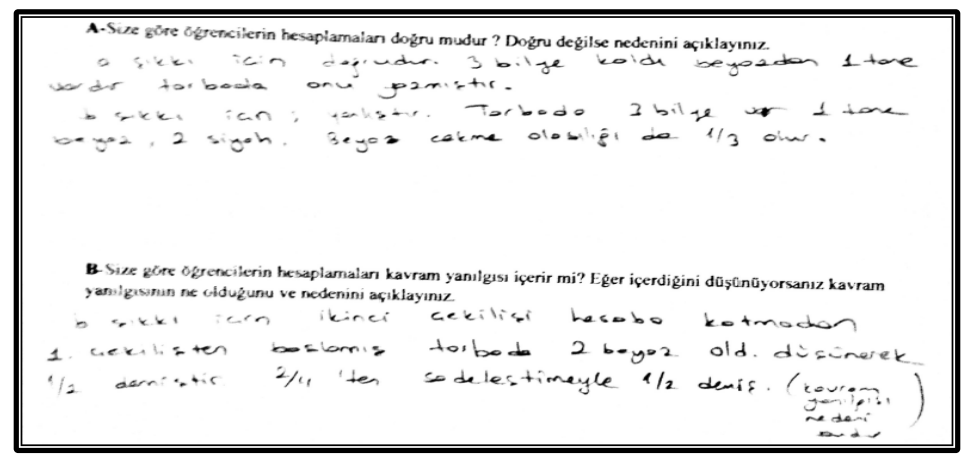

Şekil 6. $A_{3}^{\prime}$ ün dokuzuncu senaryo hakkındaki yazılı açıklaması 
$\mathrm{A}_{3}$ öğretmen adayı açıklamasında senaryoda verilen $\mathrm{a}$ ve $\mathrm{b}$ maddelerindeki cevaplardan yanlış olan b’yi fark edip doğrusunu belirtmiştir. B şıkkındaki kavram yanılgısının sebebi olarak ise ikinci çekilişin hesaba katılmadan hesap yapılmasından kaynaklandığını belirterek açıklamayı kısmen doğru yapsa da koşullu olasılık durumunu tam olarak açıklayamadığı görülmüştür. Burada öğrencilerin yanlış düşünmelerinin asıl sebebi, neden-sonuç ilişkisine bağlı düşünme ile ilk kısımdaki olay kolay hesaplanırken, ikinci kısımda bağımlı olayın, bağlı olduğu olaydan sonra gerçekleşmesi nedeniyle nedensonuç çıkarımını yapamamalarıdır.

Öğretmenlerin ve Öğretmen Adaylarının Kavram Yanılgısını Gidermeye Yönelik Kullanmayı Tercih Ettikleri Yöntemlere İlişkin Bulgular

Öğretmenlerin ve öğretmen adaylarının senaryolardaki kavram yanılgılarının ne olduğu ve nedeni sorulduktan sonra bu kavram yanılgılarının giderilmesi için hangi yöntemleri ya da teknikleri tercih ettikleri sorulmuş ve bu soruya ilişkin bulgular Tablo 12'de verilmiştir.

Tablo 12. Matematik öğretmenlerinin ve öğretmen adaylarının kavram yanılgısını gidermeye yönelik kullanılacak yöntem ile ilgili açıklamaları

\begin{tabular}{|c|c|c|c|c|c|c|c|c|c|}
\hline KK & 1.senaryo & 2.senaryo & 3.senaryo & 4.senaryo & 5.senaryo & 6.senaryo & 7.senaryo & 8.senaryo & 9.senaryo \\
\hline $\mathrm{A}_{1}$ & $\begin{array}{l}\text { Düz } \\
\text { anlatım, } \\
\text { soru } \\
\text { sorma }\end{array}$ & $\begin{array}{l}\text { Düz } \\
\text { anlatım, } \\
\text { soru } \\
\text { sorma }\end{array}$ & $\begin{array}{l}\text { Düz } \\
\text { anlatım, } \\
\text { soru } \\
\text { sorma }\end{array}$ & $\begin{array}{l}\text { Şekil, } \\
\text { örnek } \\
\text { çizme }\end{array}$ & $\begin{array}{l}\text { Somut } \\
\text { materyal }\end{array}$ & $\begin{array}{l}\text { Soru } \\
\text { sorma }\end{array}$ & - & $\begin{array}{l}\text { Somut } \\
\text { materyal }\end{array}$ & - \\
\hline $\mathrm{A}_{2}$ & $\begin{array}{l}\text { Somut } \\
\text { materyal }\end{array}$ & $\begin{array}{l}\text { Somut } \\
\text { materyal }\end{array}$ & $\begin{array}{l}\text { Somut } \\
\text { materyal }\end{array}$ & - & $\begin{array}{l}\text { Düz } \\
\text { anlatım }\end{array}$ & $\begin{array}{l}\text { Düz } \\
\text { anlatım }\end{array}$ & - & $\begin{array}{l}\text { Düz } \\
\text { anlatım }\end{array}$ & - \\
\hline $\mathrm{A}_{3}$ & $\begin{array}{l}\text { Somut } \\
\text { materyal }\end{array}$ & $\begin{array}{l}\text { Somut } \\
\text { materyal }\end{array}$ & - & - & $\begin{array}{l}\text { Canlan } \\
\text { dirma }\end{array}$ & $\begin{array}{l}\text { Somut } \\
\text { materyal }\end{array}$ & $\begin{array}{l}\text { Somut } \\
\text { materyal }\end{array}$ & $\begin{array}{l}\text { Somut } \\
\text { materyal }\end{array}$ & $\begin{array}{l}\text { Düz } \\
\text { anlatım, } \\
\text { Somut } \\
\text { materyal }\end{array}$ \\
\hline $\mathrm{O}_{1}$ & $\begin{array}{l}\text { Tartışma } \\
\text { ortamı }\end{array}$ & - & & $\begin{array}{l}\text { Benzer } \\
\text { örnek }\end{array}$ & $\begin{array}{l}\text { Benzer } \\
\text { örnek }\end{array}$ & - & - & - & - \\
\hline $\mathrm{O}_{2}$ & $\begin{array}{l}\text { Somut } \\
\text { materyal }\end{array}$ & $\begin{array}{l}\text { Düz } \\
\text { anlatım }\end{array}$ & $\begin{array}{l}\text { Düz } \\
\text { anlatım }\end{array}$ & $\begin{array}{l}\text { Düz } \\
\text { anlatım }\end{array}$ & $\begin{array}{l}\text { Düz } \\
\text { anlatım }\end{array}$ & $\begin{array}{l}\text { Düz } \\
\text { anlatım }\end{array}$ & $\begin{array}{l}\text { Düz } \\
\text { anlatım }\end{array}$ & $\begin{array}{l}\text { Düz } \\
\text { anlatım }\end{array}$ & - \\
\hline $\mathrm{O}_{3}$ & $\begin{array}{l}\text { Düz } \\
\text { anlatım }\end{array}$ & - & $\begin{array}{l}\text { Somut } \\
\text { materyal }\end{array}$ & $\begin{array}{l}\text { Benzer } \\
\text { örnek }\end{array}$ & - & - & $\begin{array}{l}\text { Benzer } \\
\text { örnek }\end{array}$ & $\begin{array}{l}\text { Benzer } \\
\text { örnek }\end{array}$ & $\begin{array}{l}\text { Benzer } \\
\text { örnek }\end{array}$ \\
\hline $\mathrm{L}_{1}$ & $\begin{array}{l}\text { Somut } \\
\text { materyal }\end{array}$ & $\begin{array}{l}\text { Deneme } \\
\text { yanılma }\end{array}$ & $\begin{array}{l}\text { Düz } \\
\text { anlatım }\end{array}$ & $\begin{array}{l}\text { Düz } \\
\text { anlatım }\end{array}$ & $\begin{array}{l}\text { Düz } \\
\text { anlatım }\end{array}$ & - & $\begin{array}{l}\text { Düz } \\
\text { anlatım, }\end{array}$ & - & $\begin{array}{l}\text { Düz } \\
\text { anlatım }\end{array}$ \\
\hline
\end{tabular}




\begin{tabular}{|c|c|c|c|c|c|c|c|c|c|}
\hline & & & & & & & $\begin{array}{l}\text { Somut } \\
\text { materyal }\end{array}$ & & \\
\hline $\mathrm{L}_{2}$ & $\begin{array}{l}\text { Düz } \\
\text { anlatım, } \\
\text { Somut } \\
\text { materyal }\end{array}$ & $\begin{array}{l}\text { Düz } \\
\text { anlatım, } \\
\text { Somut } \\
\text { materyal }\end{array}$ & - & $\begin{array}{l}\text { Benzer } \\
\text { problem }\end{array}$ & $\begin{array}{l}\text { Somut } \\
\text { materyal }\end{array}$ & - & $\begin{array}{l}\text { Düz } \\
\text { anlatım }\end{array}$ & $\begin{array}{l}\text { Düz } \\
\text { anlatım }\end{array}$ & $\begin{array}{l}\text { Düz } \\
\text { anlatım, } \\
\text { Somut } \\
\text { materyal }\end{array}$ \\
\hline $\mathrm{L}_{3}$ & $\begin{array}{l}\text { Düz } \\
\text { anlatım }\end{array}$ & $\begin{array}{l}\text { Düz } \\
\text { anlatım, } \\
\text { Örnek } \\
\text { verme }\end{array}$ & $\begin{array}{l}\text { Düz } \\
\text { anlatım, } \\
\text { Örnek } \\
\text { verme }\end{array}$ & $\begin{array}{l}\text { Düz } \\
\text { anlatım }\end{array}$ & $\begin{array}{l}\text { Düz } \\
\text { anlatım }\end{array}$ & $\begin{array}{l}\text { Düz } \\
\text { anlatım }\end{array}$ & - & $\begin{array}{l}\text { Düz } \\
\text { anlatım }\end{array}$ & - \\
\hline
\end{tabular}

- :Görüş Bildirilmedi

Tablo 12 incelendiğinde öğretmenlerin ve öğretmen adaylarının genellikle düz anlatım, soru sorma, somut materyal kullanma gibi yöntemler ve teknikler tercih ederek kavram yanılgısını düzelteceklerini belirttikleri görülmektedir. Öğretmenlerin ve öğretmen adaylarının kavram yanılgısının tespit edilmesinde ve giderilmesinde kullanılan kavram karikatürü, kelime ilişkilendirme testi, kavram haritası gibi tekniklerden hiç bahsetmemeleri geleneksel yaklaşıma dayalı yöntemleri daha çok benimsediklerini göstermektedir. Genel olarak tüm bulgular değerlendirildiğinde, öğretmenlerin tecrübeleri ve çalıştıkları okul düzeyi dikkate alındığında, mesleki kıdemin ve çalıştığı okul kademesinin katılımcıların olasılık konusunda kavram yanılgılarını belirlemede ve nedenini açıklamada çok etkili olmadığını hatta bazı yanılgılarda adayların öğretmenlere kıyasla daha fazla bilgiye sahip olduklarını göstermiştir.

\section{Tartışma ve Sonuç}

$\mathrm{Bu}$ araştırmada, öğretmenlerin ve öğretmen adaylarının olasılıkla ilgili yanılgıların farkında olup olmadıkları, bu yanılgıların ne olduğu ve nedenleri hakkında görüşleri alınmıştır. Ayrıca bu yanılgıların giderilmesi için uygulanabilecek yöntemlere ilişkin görüşleri alınmıştır. Öğretmenlerin ve öğretmen adaylarının çoğunlukla, olumlu ve olumsuzluk sonralık etkisini, birleşim yanılgısını, basit ve bileşik olaydaki kavram yanılgılarını fark edebildikleri görülmüştür. Ancak koşullu olasılık ve sonuç yaklaşımlı kavram yanılgısını ve bu yanılgının nedenini tam olarak açıklayabilen hiçbir katılımcıya rastlanamamıştır. Temsil kısa yolu kavram yanılgısına ilişkin sonuçlar incelendiğinde, özellikle ortaokul matematik öğretmenlerinin zorluk yaşadıkları görülmüşsür. Benzer şekilde Ertem-Akbaş ve Gök (2018), araştırmasında, öğrencilerin yarıya yakınında olasılık konusunda temsil edilebilirlikle ilgili kavram yanılgısı olduğunu ortaya koymuştur. 
Araştırmada ortaya çıkan sonuçlardan bir diğeri de katılımcıların çoğunun ayrık olaylar ile bağımsız olayları birbirinden ayırt edememesidir. Özellikle de adayların hiçbiri ayrık olaylar ile bağımsız olayları ayırt edememiş kendilerinin de bu yanılgılara sahip olduğu görülmüştür. Gökkurt-Özdemir (2017), yaptığı araştırmada öğretmen adaylarının ayrık olaylar ile bağımsız olayları birbirine karıştırdığı sonucuna ulaşmıştır. Benzer şekilde alanyazında pek çok çalışma, öğretmenlerde ve öğrencilerde kavram yanılgılarının var olduğunu göstermektedir (Bulut, Yetkin \& Kazak, 2002; Gökkurt-Özdemir, Bayraktar, \& Yılmaz, 2017; Işık, Kaplan, \& Zehir, 2011; Sev-Lekesiz,2011; Sezgin-Memnun, Altun, \& Yılmaz, 2010; Tunç, 2006).

Öğretmen adaylarının ve öğretmenlerin olasılık konusunda bazı yanılgıların farkında olmamalarının sebeplerinden birinin olasılık konusuna ilişkin kendilerinin de sahip oldukları kavram yanılgıları gösterilebilir. Gürbüz ve Birgin (2012), de olasılık konusunun öğretilememesinin sebeplerinden birinin bu konuyla ilgili yaygın şekilde kavram yanılgılarının olduğunu dile getirmişlerdir. Diğer bir neden olarak da katılımcıların olasılık konusunu günlük hayatla yeterince ilişkilendirememeleri ve bu konu üzerinde yeterince muhakeme yapmamaları söylenebilir. Matematiğin temel amaçlarından birisinin bireyin günlük hayatta karşılaştığı problemler karşısında etkili çözümler sunabilmesini sağlamak olduğundan matematiksel kavramları günlük hayatla ilişkilendirmek gerekmektedir (Erdem, Gürbüz, \& Duran, 2011). Olasılık konusu doğası gereği zor bir konudur (Cornu, 1991). Muhakeme matematik konularının öğrenilmesinde, konular arasında ilişkilendirme yapmada ve sonuç çıkarmada önemli bir beceridir. Öğretim programlarında da bu beceri üzerine vurgu yapılmıştır (Milli Eğitim Bakanlığı [MEB], 2013). Erdem (2011) de muhakeme becerisi ile olasılıksal muhakeme becerisi arasında yüksek ilişki olduğunu tespit etmiştir. Bu nedenle, öğretmenlerin öğrencilerine muhakeme yapabilecekleri sorular sorması ve olası kavram yanılgılarını engelleyebilmek için alanı öğretme bilgilerini geliştirmeleri gerektiği önerilmektedir. Örneğin öğretmenler, derslerinde basit ve bileşik olaylarla ilgili kavram yanılgısıyla ilgili Zawojewski ve Shaughnessy'nin (2000) öğrencilerine sorduğu soru gibi sorular kullanabilirler. Zawojewski ve Shaughnessy, 12. sınıf öğrencilerine yarısının siyah, yarısının beyaz olduğu iki çarkın olduğu bir resim vermiştir. Burada öğrencilerin her iki çarkın ortasındaki alette okların aynı anda döndürüldüğünde ikisinin de siyah gelme olasılığının \%50 olup olmadığına ilişkin görüşlerini almıştır. Öğrencilerin sadece \%8'i doğru cevap vererek bu sonuca katılmadığını düşünmüştür. Öğrencilerin yanlış düşünmelerinin 
sebeplerinden birinin çarkların yarısının siyah, yarısının da beyaz olmasıdır. Oysaki bu soruda öğrenciler örneklem uzayında siyah ve siyah, siyah ve beyaz, beyaz ve siyah, beyaz ve beyaz gelme ihtimallerini görememişler ve sorunun cevabının $\% 25$ olduğunu fark edememişlerdir. Bu doğrultuda, bu yanılgıları ortaya çıkaracak soruların sorulması, hem öğretmenlerin hem de hizmet öncesinde öğretmen adaylarını yetiştiren öğretim elemanlarının olasılık konusunda yeterli düzeyde alan ve alanı öğretme bilgisine sahip olmaları gerektiği önerilmektedir. Danişman ve Tanışlı'nın (2017) yaptıkları araştırmada öğretmen adaylarının olasılık öğretiminde pedagojik alan bilgilerinin yeterli olmadıklarını ve gelişime ihtiyaçları olduklarını ortaya çıkarmıştır. Öğretmenlerin tecrübesi daha iyi öğrenmelerinde etkili olmasına rağmen bu araştırmada tecrübeli olan öğretmenlerle adayların benzer cevaplar vermesi, alan ve alanı öğretme bilgilerinin eksik olduğunu göstermiştir.

Öğretmenlerin ve adayların kavram yanılgılarının giderilmesine ilişkin kullanmayı tercih ettikleri yöntemlere ilişkin sonuçlar incelendiğinde, seçtikleri yöntemlerin sınırlı olduğu görülmektedir. Öğretmenlerin alan ve pedagojik alan bilgisini üniversite yıllarında kazandığı dikkate alınırsa, üniversitede aldıkları eğitimin önemi ortaya çıkmaktadır. Araştırmada katılımcıların kavram yanılgılarının tespit edilmesinde ve giderilmesinde etkin olan (kelime ilişkilendirme testi, kavram haritaları, kavram karikatürleri vb.) yöntemlerden bahsetmedikleri görülmüş, genellikle düz anlatım, soru-sorma yöntemleri ile materyal kullanımını tercih ettikleri görülmüştür. Bu yöntemler dışında, Biehler (1989), bilişim teknolojilerinin olasılık öğretimini desteklemek amacıyla öğretime entegre edilmesini önermektedir. Biehler, bilgisayar simülasyon yazılımlarının temel olasılık kavramlarının öğretiminde öğrencilere pek çok deneme yapabilmeleri, daha çok veri toplayabilmeleri ve analiz edebilmeleri geniş olanaklar sağladığını belirtmiştir. Bu kapsamda, öğretmenlerin olasılık konusunun öğretiminde simülasyon yazılımlarından faydalanmaları önerilmektedir. Ayrıca derslerde öğrencilerin olasılık konusunu günlük hayatla yeterince ilişkilendirebilecekleri örneklere ve sorulara yer verilmesi gerektiği önerilmektedir. Katılımcıların tercih ettikleri yöntem-teknikler arasında soru sorma olsa da, bu yöntemi tercih edenlerin çoğu, bu soruların ve örneklerin günlük yaşamla ilişkili olmasına ve muhakeme türünden sorular olmasına vurgu yapmadıkları görülmüştür. Zawojewski ve Shaughnessy'nin (2000) sordukları sorular gibi daha üst düzeyde düşünmeyi gerektiren soruların sorulması önerilmektedir. 
Görüşme tekniğiyle sınırlı olan bu araştırmada, araştırmacıların gözlem tekniğini kullanarak, öğretmenlerin sınıf ortamında öğrencilerin sahip oldukları kavram yanılgılarının farkında olup olmadıkları ve bu yanılgıları gidermek için hangi yöntemleri kullandıkları araştırılabilir. Bu araştırmada bazı öğretmenlerin ve adayların olasılıkla ilgili kavram yanılgılarına sahip oldukları görülmüştür. Öğretmenlerin ve adayların sahip oldukları kavram yanılgılarını gidermeye yönelik gelişimsel çalışmalar yapılması önerilmektedir.

\section{Bilgilendirme}

Bu çalışma, 2017 yılında Antalya'da 27 ${ }^{\text {th }}$ International Conference on Sport, Education Sciences" konferansında sunulan sözlü bildirinin genişletilmiş halidir.

\section{Kaynaklar}

Akkoç, H. \& Yeşildere-İmre, S. (2015). Teknolojik pedagojik alan bilgisi temelli olasılık ve istatistik ögrretimi Ankara: Pegem Akademi.

Altun, M. (2008). Liselerde matematik öğretimi. Bursa: Aktüel alfa akademi.

Baki, A. (2008). Kuramdan uygulamaya matematik eğitimi (4. Basım). Ankara: Harf Eğitim Yayıncilığ

Batanero, C., Serrano, L., \& Garfield, J. B. (1996). Heuristics and biases in secondary school students' reasoning about probability. In L. Puig \& A. Gutiérrez (Eds.), Proceedings of the $20^{\text {th }}$ conference of the International Group for the Psychology of Mathematics Education (Vol.2, pp. 51-58). Valencia, Spain: University of Valencia.

Biehler, R. (1989). Educational perspectives onexploratory data analysis. In R. Morris (Ed.), Studies in mathematics education, The teaching of statistics (Vol, 7, pp. 185-201). Paris: UNESCO.

Bulut, S., Ekici, C., \& İnan-İşeri, A. (1999). Bazı olasılık kavramlarının öğretimi için çalışma yapraklarının geliştirilmesi. Hacettepe Üniversitesi Ĕ̆itim Fakültesi Dergisi, 15, 129-136.

Bulut, S., Yetkin, İ. \& Kazak, S. (2002).Matematik öğretmen adaylarının olasılık başarısı, olasılık ve matematiğe yönelik tutumlarının cinsiyete göre incelenmesi. Hacettepe Üniversitesi Ĕ̆itim Fakültesi Dergisi 22, 21-28.

Boyacığlu, H., Erduran, A., \& Alkan, H. (1996). Permütasyon, kombinasyon ve olasılık öğretiminde rastlanan güçlüklerin giderilmesi. II. Ulusal Eğitim Sempozyumu'nda sunulmuş bildiri. Marmara Üniversitesi, Atatürk Eğitim Fakültesi, İstanbul.

Cornu, B. (1991). Limits. In D. Tall (Ed.), Advanced mathematical thinking. Boston: Kluwer.

Danişman, Ş., \& Tanışlı, D. (2017). Examination of mathematics teachers' pedagogical content knowledge of probability. Malaysian Online Journal of Educational Sciences, 5(2), 16-34.

Erbaş, A. K., Çetinkaya, B., \& Ersoy, Y. (2009). Öğrencilerin basit doğrusal denklemlerin çözümünde karşılaştıkları güçlükler ve kavram yanılgıları. Eğitim ve Bilim, 34(152), 45-59. 
Erdem, E. (2011). İlkoğretim 7. sinıf oğrencilerinin matematiksel ve olasıliksal muhakeme becerilerinin incelenmesi. (Yayımlanmamış yüksek lisans tezi). Adıyaman Üniversitesi, Fen Bilimleri Enstitüsü, Adiyaman.

Erdem, E., Gürbüz, R., \& Duran, H. (2011). Geçmişten günümüze gündelik yaşamda kullanılan matematik üzerine: Teorik değil pratik. Türk Bilgisayar ve Matematik Ĕ̆itimi Dergisi, 2(3), 232-246.

Ertem-Akbaş, E. \& Gök, M. (2018). Ortaöğretim öğrencilerinin olasılık konusunda temsil edilebilirlik ile ilgili kavram yanılgıları. Yüzüncü Yıl Üniversitesi Eğitim Fakültesi Dergisi, 15(1) , 1434-1458 .

Fischbein, E. \& Schnarch, D. (1997). The evolution with age of probabilistic, intuitively based misconceptions, Journal of Research in Mathematics Education, 28(1), 96-105.

Gökkurt-Özdemir, B. (2017). Öğretmen adaylarının olasılık kavramlarına ilişkin alan bilgileri: ayrık-ayrık olmayan olaylar, bağımlı-bağımsız olaylar. Muş Alparslan Üniversitesi Sosyal Bilimler Dergisi, 5(3), 693-713.

Gökkurt-Özdemir, B., Bayraktar, R., \&Yılmaz, M. (2017). Sınıf ve matematik öğretmenlerinin kavram yanılgılarına ilişkin açıklamaları. Trakya Üniversitesi Ĕ̆itim Fakültesi Dergisi, 7(2), 284-305.

Gürbüz, R. \& Birgin, O. (2012). The effect of computer-assisted teaching on remedying misconceptions: the case of the subject "probability. Computers \& Education, 58, 931941.

Hirsch, L. S. \& O'Donnell, A. M. (2001) Representativeness in statistical reasoning: identifying and assessing misconceptions. Journal of Statistics Education, 9(2), 1-22

Hayat, F. (2009) İlköğretim 8.sını öğrencilerinin olasılıkla ilgili kavramsal ve işlemsel bilgi düzeyleri ve kavram yanılgılarının belirlenmesi. (Yayımlanmamış yüksek lisans tezi) Atatürk Üniversitesi, Fen Bilimleri Enstitüsü, Erzurum.

Işık C., Kaplan A., \& Zehir, K. (2011). İlköğretim matematik öğretmen adaylarının olasılık kavramlarını açılama ve örnekleme becerilerinin incelenmesi. Trakya Üniversitesi Ĕ̆itim Fakültesi Dergisi, 1(1), 33-51.

Kahneman, D. \& Tversky, A. (1972). Subjective probability: A judgment of representativeness. Coginitive Psychology, 3, 430-454.

Kazak, S. (2013). Öğrencilerin olasılık konularındaki kavram yanılgıları ve öğrenme zorlukları. M.F. Özmantar, E.Bingölbali ve H. Akkoç (Ed.), Matematiksel kavram yanılgıları ve çözüm önerileri (s.121-150) (3. Baskı). Ankara. Pegem Akademi.

Konold, C., Pollatsek, A., Well, A., Lohmeier, J., \& Lipson, A. (1993). Inconsistencies in students' reasoning about probability. Journal for Research in Mathematics Education, 24, 392-314.

Moralı, S. , Köroğlu, H., \& Çelik, A. (2004) Buca eğitim fakültesi matematik öğretmen adaylarının soyut matematik dersine yönelik tutumları ve rastlanan kavram yanılgıları. Gazi Üniversitesi, Gazi Eğitim Fakültesi Dergisi, 24(1),161-175.

Miles, M. B. \& Huberman, A. M. (1994). Qualitative data analysis: An expanded sourcebook. (Second Edition). California: SAGE Publications. 
Milli Eğitim Bakanlığ1 [MEB], (2013). Ortaokul matematik dersi (5, 6, 7 ve 8. Sinıflar) stnıflar ögretim programı ve kılavuzu. Ankara: Ankara: Talim ve Terbiye Kurulu Başkanlığ1

Schoen, R. C., LaVenia, M., Chicken, E., Razzouk, R., \& Kisa, Z. (2019). Increasing secondarylevel teachers' knowledge in statistics and probability: Results from a randomized controlled trial of a professional development program. Cogent Education, 6(1), 1-26

Sev-Lekesiz, E. Ç. (2011). Dördüncü ve beşinci sınıföğrencilerini olasıllk öğreniminde karşılaştıkları zorluklar. (Yayımlanmamış yüksek lisans tezi). Eskişehir Osmangazi Üniversitesi, Eğitim Bilimleri Enstitüsü, Eskişehir.

Sezgin-Memnun, D. (2008a). Olasılık kavramlarının öğrenilmesinde karşılaşılan zorluklar, bu kavramların öğrenilememe nedenleri ve çözüm önerileri. Uludă̆ Üniversitesi Ĕ̆gitim Fakültesi Dergisi, 21(2), 403-426.

Sezgin-Memnun, D. (2008b). Sekizinci sinıfta permütasyon ve olasılık konularının aktif öğrenme ile öğretiminin uygulama düzeyi öğrenci başarısına etkisi. İnönü Üniversitesi Eğitim Fakültesi Dergisi, 21(2), 403-426.

Sezgin-Memnun, D., Altun, M., \& Yılmaz, A. (2010). İlköğretim sekizinci sınıf öğrencilerinin olasılıkla ilgili temel kavramları anlama düzeyleri. Uludă̆ Üniversitesi Eğitim Fakültesi Dergisi, 23(1), 11-29.

Shaughnessy, J. M. (1992). Research in probability and statistics: reflections and directions. In D. A. Groups, (Ed.), Handbook of research on mathematics teaching and learning, Macmillan (pp. 465-494), New York.

Shaughnessy, J. M. (1993). Probabilty and statistics. Mathematics Teacher, 86(3), 244-248.

Şandır, H., Ubuz, B., \& Argün, Z. (2007). 9. Sınıf öğrencilerinin aritmetik işlemler, sıralama, denklem ve eşitsizlik çözümlerindeki hataları. Hacettepe Üniversitesi Ĕğitim Fakültesi Dergisi, 32, 274-281.

Tunç, E. (2006). Özel ilköğretim okulları ile devlet okullarının 8. sinı öğrencilerine olasılık konusundaki bilgi ve becerileri kazandırma düzeylerinin değerlendirilmesi. (Yayımlanmamış yüksek lisans tezi), Balıkesir Üniversitesi Fen Bilimleri Enstitüsü, Balıkesir.

Yıldırım, A. \& Şimşek, H. (2013). Sosyal bilimlerde nitel araştırma yöntemleri (8. Baskı). Ankara: Seçkin Yayıncılık.

Zawojewski, J. S. \& Shaughnessy, J. M. (2000). Data and change. In E. A. Silver \& P. A. Kenney (Eds.), Results from seventh mathematics assessment of the national assessment of educational progress (s. 235-268). Reston, VA: National Council of Teachers of Mathematics. 